OPEN ACCESS

Edited by:

Kuldeep Dhama,

Indian Veterinary Research

Institute (IVRI), India

Reviewed by:

Muhammad Zubair Shabbir,

University of Veterinary and Animal

Sciences, Pakistan

lgor Jurak,

University of Rijeka, Croatia

Sunil Joshi,

Old Dominion University,

United States

Maryam Dadar,

Razi Vaccine and Serum

Research Institute, Iran

*Correspondence:

Ruth E. Drury

ruth.drury@paediatrics.ox.ac.uk

Specialty section:

This article was submitted

to Microbial Immunology,

a section of the journal

Frontiers in Immunology

Received: 17 July 2017 Accepted: 06 September 2017 Published: 25 September 2017

Citation:

Drury RE, O'Connor D and Pollard AJ (2017) The Clinical Application of MicroRNAs in Infectious Disease.

Front. Immunol. 8:1182. doi: 10.3389/fimmu.2017.01182

\section{The Clinical Application of MicroRNAs in Infectious Disease}

\author{
Ruth E. Drury*, Daniel O’Connor and Andrew J. Pollard \\ Oxford Vaccine Group, Centre for Clinical Vaccinology and Tropical Medicine, Department of Paediatrics, University of \\ Oxford, The Churchill Hospital, Oxford, United Kingdom
}

MicroRNAs (miRNAs) are short single-stranded non-coding RNA sequences that posttranscriptionally regulate up to $60 \%$ of protein encoding genes. Evidence is emerging that miRNAs are key mediators of the host response to infection, predominantly by regulating proteins involved in innate and adaptive immune pathways. miRNAs can govern the cellular tropism of some viruses, are implicated in the resistance of some individuals to infections like HIV, and are associated with impaired vaccine response in older people. Not surprisingly, pathogens have evolved ways to undermine the effects of miRNAs on immunity. Recognition of this has led to new experimental treatments, RG-101 and Miravirsen-hepatitis C treatments which target host miRNA. miRNAs are being investigated as novel infection biomarkers, and they are being used to design attenuated vaccines, e.g., against Dengue virus. This comprehensive review synthesizes current knowledge of miRNA in host response to infection with emphasis on potential clinical applications, along with an evaluation of the challenges still to be overcome.

Keywords: microRNAs, infection, epigenetics, biomarkers, vaccines

\section{INTRODUCTION}

In 1993, Ambros et al. made a surprise discovery while trying to unpick the fundamental mechanisms underlying gene expression in the nematode. They discovered a 22 nucleotide RNA sequence that controlled expression of a protein encoding gene (1). Initially thought to be a peculiarity of nematodes, the next decade brought the discovery of hundreds of 20-24 nucleotide RNA molecules in viruses, plants, animals and humans, and what's more, these small RNA molecules were able to regulate the expression of genes (2). These tiny single-stranded transcripts became known as microRNAs (miRNAs, miRs) and led to a paradigm shift in our understanding of gene regulation. Utilizing the mechanics of the RNA interference pathway, miRNAs bind to complementary sequences in the 3' untranslated region of messenger RNA transcripts, to prevent translation (3). miRNAs fine tune protein production after a gene has been transcribed. Although the study of miRNA is still in its relative infancy, it is clear that miRNAs are key mediators of gene expression. The miRNA registry, miRbase, lists 2558 human miRNAs, and collectively these miRNAs regulate an estimated $60 \%$ of protein-coding genes $(4,5)$. miRNAs are critical controllers of cell differentiation and functions,

Abbreviations: $3^{\prime} \mathrm{UTR}, 3^{\prime}$ untranslated region; 5'UTR, 5' untranslated region; AID, activation-induced cytidine deaminase; EV-71, enterovirus 71; HBV, hepatitis B virus; HCMV, human cytomegalovirus; HCV, hepatitis C virus; HESN, HIV-exposed seronegative individuals; HSV, herpes simplex virus; miRNA, microRNA; MRE, microRNA response element; RISC, RNA induced silencing complex; siRNA, small interfering RNA; TB, tuberculosis; TLR, toll-like receptor. 
mediating a variety of cellular processes including those integral to innate and adaptive immunity (6-15). Unsurprisingly, pathogens have evolved to exploit host miRNAs to subvert the immune response (16-34). Characterization of the physiological roles of miRNAs in immunity has led to the pursuit of miRNA-based tests and treatments, and 24 years after the discovery of the first miRNA, the clinical application of miRNAs in infectious disease is starting to be realized. This review summarizes the role of miRNAs in host response to pathogens and reviews the promising clinical applications of miRNAs in preventing, diagnosing, and treating infections.

\section{MICRORNAs}

MicroRNA biogenesis and mechanism of action are summarized in Figure 1 (35-39). Key terminology is outlined in Box 1. As noted above, miRNAs bind to complementary sequences in the 3 ' untranslated region of mRNA transcripts. miRNA molecules do not require perfect complementarity to bind $\mathrm{mRNA}$, indeed only nucleotides 2-7 of a miRNA (termed the "seed region") have to match a site on a mRNA perfectly for binding to occur (40). Therein lies the complexity of miRNA-mediated gene regulation; namely one miRNA can bind hundreds of different mRNAs, and

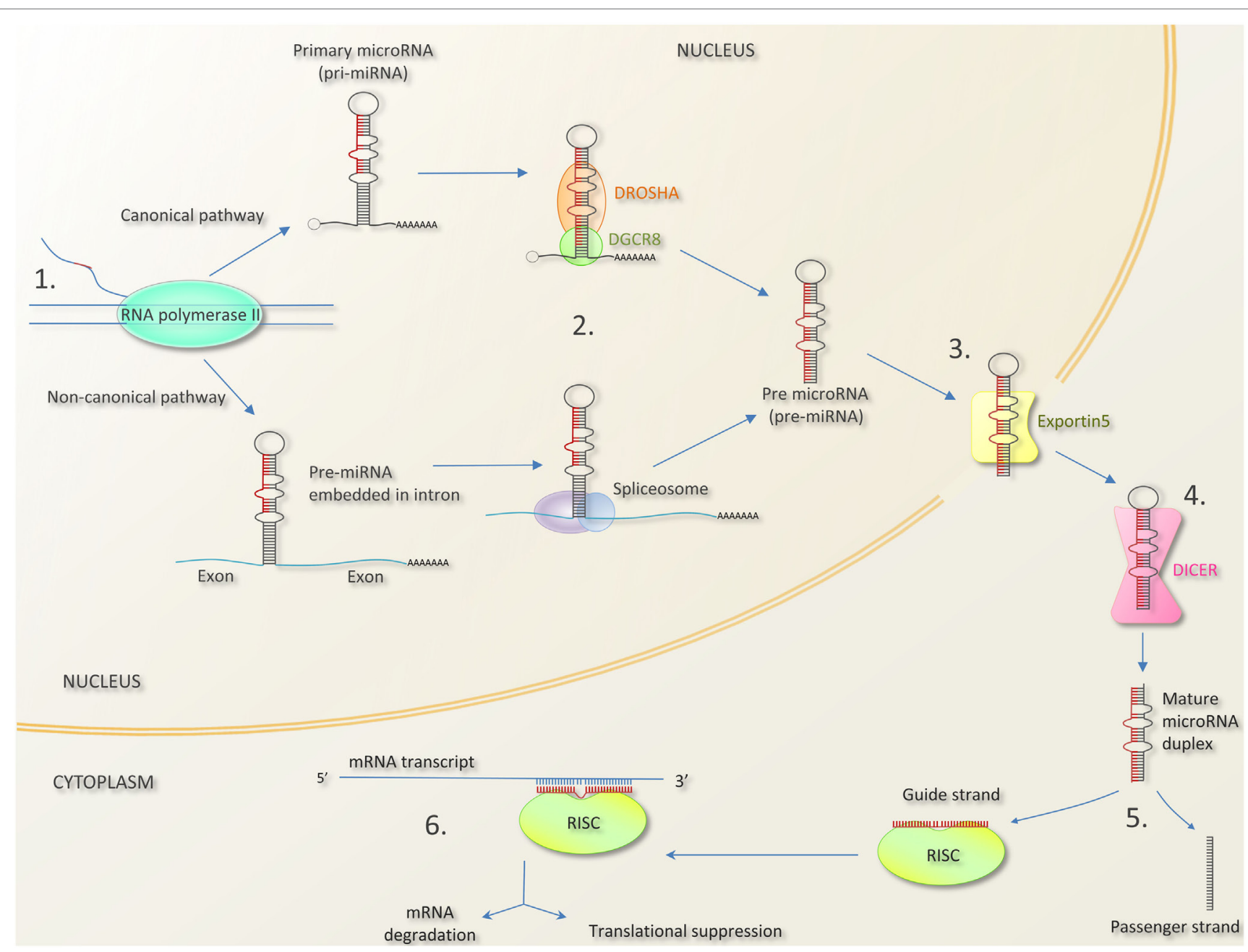

FIGURE 1 | MicroRNA biogenesis and mechanism of action [composed from Ref. (35-39)]. 1. MicroRNA genes can be found as independent transcriptional units, or embedded within introns, and occasionally exons of other genes. In the canonical pathway, microRNA are transcribed as long primary miRNA transcripts (pri-miRNAs) by RNA polymerase II (and occasionally RNA polymerase III). Pri-miRNAs can be several kilobases long and can contain the stem loops of several mature miRNAs (giving rise to miRNA clusters-see Box 1). In the non-canonical pathway, miRNA precursors lie in mRNA introns ("miRtrons"). 2. Pri-miRNAs are processed by the nuclear protein DGCR8 (DiGeorge syndrome critical 8 region) and the enzyme DROSHA into hair pin shaped structures called pre-miRNA transcripts. In the non-canonical pathway, miRNA precursors in mRNA introns are spliced out and bypass DGCR8/DROSHA. 3. Pre-miRNAs are exported to the cytoplasm by exportin-5. 4. The enzyme DICER cleaves the pre-miRNA hairpin loop to produce a mature miRNA duplex. 5. One strand of the miRNA duplex (the guide strand) associates with Argonaut (AGO) protein in the RNA induced silencing complex (RISC). The remaining strand (termed the passenger strand) is degraded. In most cases, there is a preference for which strand is incorporated due to factors like thermodynamic stability. 6 . The mature single-stranded miRNA in the miR-RISC complex binds to complementary sequences in the $3^{\prime}$ untranslated region of mRNA molecule, preventing translation. Bound mRNA may be degraded or stored for translation later (48). Bound mRNA may be sequestered into processing bodies (p-bodies) possibly for later release (49). 


\section{BOX 1 | Terminology.}

Nomenclature. microRNA is commonly condensed to miRNA or miR. Initial miRNAs discovered in Caenorhabditis elegans were prefixed with "lin" and "let," e.g., lin-4 and let-7. Subsequently miRNAs have been numbered in the order in which they were discovered, e.g., miR-1. Their prefix is usually shortened to miR and often prefixed by their species, e.g., hsa-miR-21 (homosapien-microRNA-21).

$-5 p$ and $3 p$ suffixes: Denotes whether the mature miRNA is derived from the $5^{\prime}$ arm or the $3^{\prime}$ arm of the stem loop precursor: e.g., hsa-miR-21-3p, hsa-miR-21-5p

* suffix: $A$ * suffix denotes the miRNA strand from the miRNA duplex that is less abundantly expressed as determined by experiment, e.g., miR-56 (the predominant product) and miR-56* (the opposite miRNA strand). This annotation has been generally superseded by the $-5 p /-3 p$ suffix.

miRNA family: Closely related miRNAs whose mature sequences differ by 1 nucleotide, e.g., the let-7 family, comprising of let-7a, let-7b, let-7c, etc.

miRNA cluster: Some miRNA genes are found grouped together in polycistronic units with a shared promoter meaning they are transcribed together as a long primary transcript and are therefore coexpressed. E.g., miR-17-19 cluster.

Micronome: The entire miRNA expression profile of a cell or sample.

Seed sequence: Nucleotides 2-7 from the 5' end of the miRNA molecule. Canonical targeting of mRNAs requires that the miRNA seed sequence be perfectly complementary to an mRNA site for binding to occur.

MicroRNA response element (MRE): the miRNA binding site on an mRNA molecule

AntagomiR/antimiR: A miRNA inhibitor-an artificially produced singlestranded RNA molecule which is perfectly complementary to (and therefore binds to) a target miRNA molecule preventing the miRNA from functioning.

miRNA mimics: artificially produced analogs of miRNAs. Used to artificially upregulate the levels of specific miRNAs.

RNA interference (RNAi), small interfering RNAs (siRNA), and miRNA.

Small interfering RNAs (siRNAs) are double-stranded RNA molecules which bind to targets with perfectly homologous sequences. MicroRNA and siRNA have analogous but not identical biogenesis. siRNAs are produced from DICER cleavage of endogenously (e.g., mRNA transcript) or exogenously (e.g., viral transcript) derived long double-stranded transcripts. MicroRNA and SiRNA pathways conjoin at the point where the guide strand is loaded into RISC complexes (50). Unlike miRNAs, siRNA bind targets with perfect complementarity resulting in mRNA cleavage. In line with several authors this review uses RNAi as an umbrella term for the process of miRNA and siRNA molecules interfering with gene expression. It should be noted that some authors ascribe RNAi solely to the process of siRNA mRNA degradation.

one mRNA can bind several miRNAs, with bound miRNAs cooperatively controlling mRNA transcript translation (41). Generally speaking, binding of miRNA molecules blocks translation and promotes mRNA degradation but this might not always be the case. miRNA binding to $5^{\prime}$ untranslated regions (5'UTRs), exons and even DNA elements has been described and may enhance translation and transcription, respectively (42-47).

The overall effect of a miRNA on a gene's protein expression depends on whether its transcript is a direct or indirect target of the miRNA; for example when a miRNA targets a protein's repressors, that miRNA will indirectly upregulate that protein (the so-called repressor of a repressor effect) (51). The direct and indirect effects of miRNA can therefore lead to protein and pathway repression or enhancement. miRNAs fine tune gene expression often by involvement in complex negative feedback loops and feed-forward mechanisms. (A feedforward mechanism describes a situation where a protein coding transcript and a miRNA targeting that transcript are simultaneously induced by the same factor; this enables a protein to be expressed but not excessively so.) miRNAs may set an expression level threshold which a transcript must reach before protein translation occurs (i.e., the point at which a transcript is so abundant that the inhibitory effects of miRNAs are overcome and protein translation occurs) $(11,51)$. miRNAs frequently target several proteins in the same or connected pathways $(11,51)$.

\section{MICRORNAs ARE IMPORTANT CONTROLLERS OF LEUKOCYTE DEVELOPMENT}

Evidence that miRNAs are important in the immune system first arose from mice studies showing that the production of mature $B$ and $\mathrm{T}$ lymphocytes is altered by manipulating miRNA expression in hematopeotic stem cells and immature lymphyocytes $(7,8,10)$. These early studies revealed that miRNAs are pivotal mediators of lymphocyte development and differentiation. More recent work showed that different stages of T-cell development have characteristic, stage-specific miRNA expression profiles, and cell lineage fate (e.g., CD4+, CD8+) is determined by miRNA expression $(52,53)$. miRNAs also create thresholds which prevent naive T-cells differentiating into effector cells in the absence of significant T-cell receptor activation. For example, naive T-cells, highly express miR-125b which targets factors that promote differentiation (including interferon gamma, IL2-subunit receptor beta, IL10-subunit receptor alpha, and BLIMP1) and differentiation into an effector T-cell will only occur after a reduction in miR-125b caused by T-cell receptor activation (54). miR-125b, miR-181, miR-146, miR-155, miR-150, miR-21, and the miR 17-19 cluster appear particularly important in regulating T-lymphocyte development (55). A similar set of miRNAs, miR-21, mir-34, mir-125, mir-146, mir-155, mir-150, and mir-181 are important in B-cell development and function (56). These miRNAs govern many aspects of immunity, not just lymphocyte development, and are frequently identified as biomarkers of infection (see Biomarker section and tables in Supplementary Material), reflecting their integral role in immune response.

\section{MICRORNAs MEDIATE INNATE AND ADAPTIVE IMMUNITY}

MicroRNAs have been investigated in the host-pathogen interactions of more than 50 different infections (Table 1). Table S1 in Supplementary Material contains information on which miRNAs have been implicated in these infections along with their proposed targets. Cells isolated from patients infected with viral, fungal, and bacterial infections have different miRNA expression profiles compared with healthy controls, and this is also the case for infected versus non-infected cells in vitro $(27,57-62)$. miRNA regulation has been described in a wide range of leukocytes and in the innate immune responses of non-leukocytes $(12,34$, 63-71). Indeed, single nucleotide polymorphisms in miRNA loci 
TABLE 1 | MicroRNAs mediate the host-pathogen interactions of the following pathogens.

Viral infections Bacterial infections

\section{Fungal infections}

Chikungunya virus [Selvamani et al. (77)]

Human Cytomegalovirus [Hook et al. (78)]

Coxsackie virus [Tong et al. (79)]

Dengue virus [Smith et al. (80)]

Ebola virus [Duy et al. (81)]

Epstein-Barr virus [Gao et al. (82)]

Enterovirus 71 [Ho et al. (83)]

Hantavirus [Shin et al. (84)]

Hepatitis B virus [Li et al. (85)]

Hepatitis C virus [Luna et al. (86)]

Herpes Simplex 1 virus [Pan et al. (87)]

Human immunodeficiency virus [Xu et al. (88)]

Human papilloma virus [Harden et al. (89)]

Rotavirus [Chanda et al. (90)]

Human T-cell leukemic virus 1 [Bai and Nicot (91)]

Influenza virus [Tambyah et al. (92)]

Japanese encephalitis virus [Zhu et al. (93)]

Kaposi's sarcoma-associated herpes virus [Lagos et al. (94)]

Polio virus [Perwitasari et al. (95)]

BK Polyoma virus [Broekema and Imperiale (96)]

JC Polyoma virus [Rocca et al. (97)]

Rabies virus [Shi et al. (98)]

Respiratory syncytial virus [Thornburg et al. (99)]

Vaccinia virus [Grinberg et al. (22)]

Varicella zoster virus [Qi et al. (100)]

West Nile virus [Chugh et al. (101)]

Zika virus [Pyiro et al. (102)]
Brucella spp. [Budak et al. (103)]

Francisella tularensis [Bandyopadhyay et al. (104)]

Helicobacter pylori [Teng et al. (105)]

Haemophilus influenza [Tay et al. (106)]

Klebsiella pneumonia [Teng et al. (71)]

Mycobacterium leprae [Jorge et al. (107)]

Listeria moncytogenes [Johnston et al. (108)]

Mycobacteria tuberculosis [Rothchild et al. (109)]

Neisseria meningitides [Liu et al. (110)]

Bordetella pertussis [Ge et al. (111)]

Salmonella enterica [Maudet et al. (27)]

Staphylococcus aureus [Jin et al. (112)]

Orientia tsutsugamushi [Tsai et al. (113)]

Streptococcus pneumoniae [Griss et al. (114)]

Haemophilus influenzae [Tay et al. (106)]

Burkholderia pseudomallei [Fang et al. (115)]
Aspergillus fumigatus [Dix et al. (116)], Candida

albicans

Muhammad et al. (60)

\section{Parasitic infection}

Angiostrongylus cantonensis

[Yu et al. (117)]

Cryptosporidium parvum [Gong et al. (66)]

Leishmania major

[Lemaire et al. (58)]

Malaria falciparum

[Mantel et al. (118)]

Schistosomia japonicum [He et al. (119)]

Toxoplasma gondii [Cannella et al. (120)]

The most frequently studied organisms are highlighted in bold. 
have been associated with susceptibility to leprosy and infection outcome in human cytomegalovirus (hCMV) and hepatitis B infection (72-76). Although confirming the functional nature of such associations is difficult, the findings of such studies are in keeping with the important role of miRNAs in immunity and provide some evidence that person to person variation in susceptibility to infection could be governed by polymorphism in miRNA genes, at least for certain pathogens. Key concepts of how miRNAs mediate immunity are illustrated in Figure 2.

The activation of innate immune cells such as macrophages, dendritic cells, and natural killer cells are controlled by miRNAs (14, 50, 121-125). For example, dendritic cells exposed to mycobacteria, gram-negative and gram-positive bacteria downregulate miR-155, miR-505, miR-7, and miR-940 which alleviates translational repression of proteins involved in innate immune responses (126). miRNAs allow cells to respond rapidly to their surroundings for example, activation of resting NK-cells leads to downregulation of miR-30e which derepresses its target perforin thus enabling prompt cytolysis of infected cells (127). In this way, miRNAs prevent aberrant expression of proinflammatory molecules in the absence of inflammatory stimuli (Figure 2A). miRNAs can also promote inflammatory responses by inhibiting the translation of genes that supress inflammation (Figure 2B).

The plethora of pathogens faced by hosts demands a nuanced immune response which can adapt to cope with viral, bacterial, fungal and protozoal infections. miRNAs facilitate this nuanced inflammatory response through their control of macrophage polarization and T-cell differentiation, thereby mediating the skewing of T-cell immunity toward a T-helper (TH) 1 or TH2 response (Figure 2C). miR-29 for example limits TH1 cell differentiation by targeting mRNAs encoding T-bet, eomesodermin and IFN-gamma which promote TH1 differentiation (15).

A balanced immune response is essential if pathogens are to be eradicated with minimal collateral damage to the host otherwise immune dysregulation as seen in sepsis or chronic inflammation ensues leading to protracted illness and even death. The balance that miRNA provides is best illustrated by their regulation of tolllike receptor (TLR) signaling. TLR signaling induces miRNAs which target many elements of TLR signaling pathways including TLRs themselves, signaling proteins, regulatory molecules,

\begin{tabular}{|c|c|c|c|}
\hline \multicolumn{2}{|r|}{ Principles of miRNA regulation of immune responses } & \multicolumn{2}{|c|}{ Example } \\
\hline A & $\begin{array}{l}\text { MicroRNAs can induce a poised cellular state, } \\
\text { allowing rapid effector responses once activated } \\
\text { (i.e. expression of miRNAs that target } \\
\text { proinflammatory transcripts under resting } \\
\text { conditions enables proinflammatory/effector } \\
\text { genes to be switched on in anticipation of an } \\
\text { activating signal without protein being } \\
\text { produced). Cellular infection/leukocyte } \\
\text { activation triggers downregulation of the } \\
\text { miRNA, alleviating translational repressing, } \\
\text { leading to rapid production of the antimicrobial } \\
\text { proteins }\end{array}$ & $\underset{\text { parvum }}{\text { Cryptosporidium }} \longrightarrow$ miR-221—ICAM1 $\longrightarrow \begin{array}{c}\text { Transmigration of } \\
\begin{array}{c}\text { leukocytes to site of } \\
\text { infection }\end{array}\end{array}$ & $\begin{array}{l}\text { Infection of epithelial cells with Cryptosporidium parvum leads to } \\
\text { downregulation of miR-221, releasing intercellular adhesion molecule-1 } \\
\text { from translational repression, thereby promoting transmigration of } \\
\text { leukocytes to site of infection, facilitating pathogen eradication. }\end{array}$ \\
\hline B & $\begin{array}{l}\text { MicroRNAs promote can repress the translation of } \\
\text { proteins that inhibit an antimicrobial response. }\end{array}$ & $\begin{array}{l}\text { Vesicular } \\
\text { stomatitis } \\
\text { virus }\end{array}$ miR-155_ SOCS1 $\longrightarrow$ Interferon signalling & $\begin{array}{l}\text { Infection of macrophages with vesicular stomatitis virus leads to } \\
\text { upregulation of miR-155 via the RIG-I pathway, and targets suppression } \\
\text { of cytokine signalling } 1 \text { (SOCS1), permitting transduction of type } 1 \\
\text { interferon which leads to viral clearance }\end{array}$ \\
\hline C & $\begin{array}{l}\text { MicroRNAs can direct immune responses } \\
\text { towards a } \mathrm{T}_{H} 1 \text { or } \mathrm{T}_{H} 2 \text { type, thereby adapting } \\
\text { immune responses to whichever is most } \\
\text { effective against the invading pathogen. }\end{array}$ & 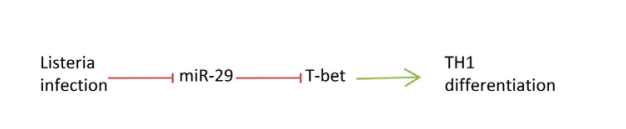 & $\begin{array}{l}\text { Listeria infection in vivo, leads to a downregulation of miR-29 in } \mathrm{T}_{\mathrm{H}} 0 \\
\text { cells, which relieves T-bet inhibition of } \mathrm{T}_{H} 1 \text { differentiation - facilitating } \\
\text { a cytotoxic T-cell response. }\end{array}$ \\
\hline D & $\begin{array}{l}\text { MicroRNAs are embedded in complex signalling } \\
\text { networks of the immune response. Their } \\
\text { involvement create positive and negative } \\
\text { feedback loops that promotes pathogen } \\
\text { eradication without an uncontrolled } \\
\text { inflammatory response that could harm the host }\end{array}$ & 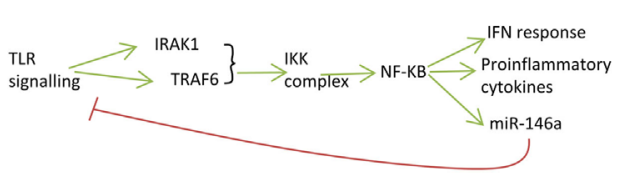 & $\begin{array}{l}\text { TLR signalling is transduced by IRAK1 and TRAF6 and leads to activation } \\
\text { of NF-KB which leads to upregulation of the interferon pathway, and } \\
\text { proinflammatory cytokines which promote an antimicrobial response. } \\
\text { NF-KB also induces transcription of miR-146a which then targets IRAK1 } \\
\text { and TRAF6 in a negative feedback loop. This regulates proinflammatory } \\
\text { cytokines production which could deleterious if left unchecked. }\end{array}$ \\
\hline $\mathbf{E}$ & $\begin{array}{l}\text { Cells may express miRNAs that repress factors } \\
\text { required for pathogen survival, making the cell } \\
\text { resistant to infection, thereby dictating tissue } \\
\text { tropism }\end{array}$ & miR-1236 $\longrightarrow \begin{array}{c}\text { Viral protein R } \\
\text { binding protein } \\
(\text { VprBP) }\end{array} \longrightarrow$ infection & $\begin{array}{l}\text { Constitutive expression of hsa-miR-1236 in monocytes binds Vpr (HIV- } \\
\text { 1)-binding protein, a factor necessary for efficient HIV infection, } \\
\text { explaining why monocytes are refractory to HIV infection }\end{array}$ \\
\hline $\mathbf{F}$ & $\begin{array}{l}\text { MicroRNAs may target sequences in a } \\
\text { pathogen's genome or transcripts leading to } \\
\text { destabilisation of the genome or transcriptional } \\
\text { or translational inhibition. }\end{array}$ & miR-296-5p $\longrightarrow$ Enteroviral-71 genome & $\begin{array}{l}\text { Cellular infection with enterovirus upregulates hsa-miR-296-5p which } \\
\text { then directly targets the enteroviral genome preventing enteroviral } \\
\text { replication }\end{array}$ \\
\hline
\end{tabular}

FIGURE 2 | Key ways microRNAs (miRNAs) mediate immune responses to pathogens. (A-F) A variety of ways in which miRNAs regulate immune responses. 
transcription factors and cytokines $(6,9,13,125,128-130)$. This creates complex feedforward and feedback loops which enables fine-tuning of TLR signaling to ensure pathogens are irradiated in a controlled manner (13) (Figure 2D). miRNA regulation of TLR signaling is a large subject which has been reviewed elsewhere (131) and therefore an extensive discussion is beyond the scope of this review, nevertheless it is useful to briefly mention miR-155 and miR-146 as these are frequently identified in studies investigating host-pathogen interactions. miR-155 is induced by TLR-2, TLR-3, TLR-4, and TLR-9 signaling in many cell types and generally functions as a proinflammatory miRNA through its targeting of factors which negatively regulate inflammation, e.g., SH2-containing inositol $5^{\prime}$-phosphatase 1 , suppression of cytokine signaling 1 $(13,130,132)$. To prevent excessive inflammation however, miR-155 expression must be controlled. In macrophages, TLR-4 signaling induces both miR-155 and IL-10, an anti-inflammatory cytokine that inhibits transcription of miR-155; this system ensures a check in the upregulation of miR-155 and therefore the inflammation it induces (133). miRNAs also negatively regulated inflammation and miR-146a is a prime example. miR-146a negatively regulates TLR signaling through a negative feedback loop involving its targets IRAK1 and TRAF6 which ensures a check in the proinflammatory signaling of NF- $\kappa \beta(124,125)$.

Although miRNAs such as miR-155 and miR-146a are generally seen as positive and negative regulators of inflammation, respectively, it should be remembered that most miRNAs are likely to be pleiotropic in infection, with net result dependant on the transcription factors and signaling molecules which are concurrently shaping cell response and cell differentiation. miR155 , for example, may promote inflammation as noted above, but in some circumstances it may also negatively regulate NF- $\kappa \beta$ activation thereby controlling inflammation (134). The targets of a miRNA can differ from cell type to cell type so the action of a miRNA in a macrophage for example may be different to its action in a neutrophil, or TH1 lymphocyte; care should be taken to avoid generalizing the findings from one cell type to another and it would be a gross oversimplification to classify most miRNAs as proinflammatory or anti-inflammatory (109). Care should also be taken in generalizing the results of in vitro experiments to the in vivo setting, and in generalizing mice studies to humans as the micronome and targets of miRNA can vary in vitro compared to in vivo and can be organism specific (135).

Another process tight controlled by of miRNAs is the production of high affinity antibodies. During infection/postvaccination, B-cells, T-follicular helper cells, and dendritic cells form germinal centers in lymphoid tissue. miRNAs are integral to this antibody affinity maturation process, evidenced by studies showing germinal center formation does not occur if there is global knockout out of miRNAs in B-cells (through conditional knock out of DICER) prevents germinal center formation. Within these germinal centers, activated B-cells undergo clonal expansion and mutate their B-cell receptors (somatic hypermutation) which are then tested against antigen bound by follicular dendritic cells in the presence of T-follicular helper cells. B-cells enter apoptosis unless their B-cell receptor strongly binds antigen in which case they receive cell survival signals from T-follicular helper cells which causes upregulation of miR-155 which then targets proapoptotic factors (e.g., JARID2) and reverses the apoptotic pathway (136). Surviving B-cells may undergo further rounds of clonal expansion, somatic hypermutation and antigen presentation; a process which ultimately yields a population of B-cells with high affinity antibodies.

Mutation of the B-cell receptor (through somatic hypermutation) and immunoglobulin class switching is regulated by miRNAs. Activation-induced cytidine deaminase (AID) catalyzes mutation of the immunoglobulin locus and is integral to class switching and affinity maturation but must be tightly controlled to prevent off target mutations and an overzealous mutational rate that can lead to oncogenic mutations and, for unclear reasons, low affinity and autoreactive antibodies (137-139). AID transcripts are targeted in resting B-cells by high levels of miR-181b. miR-181b is downregulated after activation, allowing AID expression and thus class switching and somatic hypermutation. To tightly regulate AID expression, B-cell receptor signaling induces miR-155 (which targets AID transcripts) at the same time as $\operatorname{AID}(65,138,140)$. Coinduction of AID and miR-155 after B-cell receptor stimulation creates a system in which AID is rapidly induced and then rapidly brought undercontrol, preventing immune pathology $(11,138)$.

Given the pivotal role of miR-155 in the germinal center response, dysregulation of miR-155 could lead to immune dysfunction in humans; supporting this is the finding that naive B-cells of elderly people have higher levels of mir-155 compared with young people, and this inhibits class switching in the B-cell of elderly people due to increased downregulation of AID. These findings indicate that miRNA modulation of immunity is a finely balanced process and increased susceptibility to infection and possibly poor vaccine responses in elderly people may in part be due to age-related dysregulation of miRNAs $(141,142)$. Such a conclusion is further supported by a study showing an age-associated decline in miR-125b expression in monocytes and naive CD8+ T-cell correlates with an age-associated increase in expression of its target chemokine (C-C motif) ligand 4 (CCL4) (143). CCL4 is a chemokine that promotes leukocyte migration, activation and T-cell differentiation, and its aberrant over expression in elderly people is thought to contribute to a chronic inflammatory state, leading the authors to suggest that changes in miR-125b with age may underlie age-associated chronic inflammation.

As well as shaping cell response to infection, miRNAs may play a role in determining the tropism of viruses and intracellular bacteria $(23,27,91,144)$ (Figure 2E). Primary monocytes for example are resistant to HIV infection, and this appears to be due to endogenous expression of miR-1236 which targets $\mathrm{Vpr}$ (HIV-1)-binding protein (144).

\section{HOST miRNAs MAY TARGET PATHOGENS DIRECTLY}

In addition to regulating leukocyte response, miRNAs themselves may be independent effectors of innate immunity by directly targeting viral transcripts (see Table S1 in Supplementary Material). In vitro studies show miRNA target influenza; vesicular stomatitis virus, human T-cell leukemia virus 1; human papilloma virus; and enterovirus 71, and inhibit viral replication (Figure 2F) 
facilitating pathogen clearance or potentiating viral latency (91, 145-149). Malaria transcripts have also shown to be targeted by host miRNAs translocating into the parasite (150). Indeed, miRNAs may partially dictate the cell tropism of a virus due to their targeting of viral transcripts, e.g., the resistance of resting T-cells to human T-cell leukemia virus appears to be due to their expression of mir-28-3p (91). Not everyone agrees that miRNA directly target viral transcripts, Bogerd et al. argue that cellular miRNAs do not target viruses as global downregulation of host cell miRNAs (via DICER knockout) did not lead to enhancement of 11 viruses in human embryonic kidney cell line 293T (151). Bogerd et al.'s model is problematic however as viruses may be dependent on cell mechanisms which are controlled by miRNAs and also the usual host cell of the viruses in their study are not human embryonic kidney cells. Contrary to Bogerd et al's study, there is evidence that direct targeting of viral genome/transcripts occurs in vivo as several groups have successfully attenuated viral vaccines by incorporating human miRNA seed sites in viral genome (see The Clinical Applications of miRNAs: Improving Vaccines) (152). The relative importance of miRNA direct targeting of viruses in innate immunity remains to be seen however as in vivo and in vitro studies show viral mutation of miRNA seed sites in viral genomes means viruses can quickly evolve to avoid being targeted by miRNAs $(149,153)$.

\section{EXTRACELLULAR mIRNAs AND HOST RESPONSE TO PATHOGENS}

MicroRNAs secreted from cells are called extracellular miRNAs (ex-miRNAs, circulating miRNAs). Extracellular miRNAs can be isolated from most biological fluids (154-156). Ex-miRNAs are contained in extracellular vesicles (exosomes, microvesicles, and apoptotic bodies), and through their association with Argonaut protein (a component of the RISC complex-see Figure 1) and high-density lipoprotein (154, 157-159). The biological function of ex-miRNAs is debated; they may be actively secreted as intercellular communicators of gene regulation; actively secreted as a cellular waste disposal method; or passively secreted as a byproduct of cell death (160). Although all three theories may be correct there is increasing evidence that ex-miRNA are functional, can be passed between leukocytes in vitro and in vivo, and play a role in disease (161-164). Supporting a functional role is the finding that, miR-233 and miR-29a are upregulated in the serum, and unstimulated PBMCs of HIV-exposed seronegative individuals (HESN) compared with healthy controls (165). PBMCs from HESN individuals release greater amounts of miR-223 and miR-29a when infected with HIV in vitro and infection is also better controlled, prompting the study's authors to speculate that miR-223 and miR-29a could represent novel therapeutic targets. Ex-miRNAs have been implicated in the pathophysiology of infection, for example Malaria falciparum infected erythrocytes secrete extracellular vesicles containing miR-451a which are taken up by endothelial cells and downregulate proteins required to maintain integrity of the endothelium again suggesting that miRNA-based therapies could hold promise (118) (this issues of this are discussed in the section below on treatments). A key issue for establishing the role of ex-miRNA in infectious disease is identifying the donor and recipient cells of miRNA. The surface marker proteins of exosomes (e.g., CD44) may help in this respect, but miRNA bound to protein and HDL is more difficult to track (166). Regardless of what they do, one clinical application of ex-miRNA is the use of them biomarkers of infectious disease. This is discussed in detail in the Biomarker section.

\section{INTRACELLULAR PATHOGENS EXPLOIT HOST MIRNAS}

Since miRNAs are part of an effective immunological response, intracellular pathogens have evolved ways of utilizing host miRNAs to create an immune tolerant environment that promotes pathogen survival and latency (Figure 3) (19). One of the first examples of this was the discovery that the hepatitis $C$ virus (HCV) is restricted to hepatocytes because it depends on expression of miR-122 (a liver specific miRNA) to survive and replicate (23) (Figure 3A). miR-122 binds to the HCV genome in two places, including the $5^{\prime}$ UTR and this creates a $3^{\prime}$ overhang which protects the virus from nuclear degradation $(167,168)$. Cellular miRNAs can also promote viral latency. For example, during latent hCMV infection, host miRNAs miR-200c and miR-200b target the transcript of a hCMV protein (UL122) which promotes the lytic replication, thereby promoting latency, and allowing it to persist within the host (169). The switch from viral latency to reactivation can also be facilitated by miRNAs targeting viral transcripts which inhibit lytic replication (20).

Viruses such as enterovirus, CMV, human papilloma virus, hepatitis B virus (HBV), and HCV, manipulate the expression of specific cellular miRNAs to inhibit translation of proinflammatory proteins $(16,17,21,24,25,27,29,32,33)$ (Figures 3B,C). For example, Epstein-Barr virus latent membrane protein 1 induces miR-146a expression to negatively regulate the interferon response and promote its survival (17). Manipulation of host miRNAs can occur indirectly through induction or repression of transcription factors, or in some cases may occur directly through viral sequestration of host miRNAs. In the latter case, viral transcripts bind cellular miRNAs through the production of small RNA molecules which are complementary to miRNAs (essentially virally produced antagomiRs) or through multiple cognate miRNA binding sites in miRNA decay elements or long 3'UTRs (miRNA sponge effect) (86, 131, 170-172). This sequestration blocks miRNA function and may promote miRNA decay, preventing miRNAs downregulating host transcripts that are advantageous to viral survival or replication.

There is evidence that some viruses such as HIV, dengue, vaccinia, Epstein-Barr virus, Human papilloma virus 16, and HBV globally suppress miRNA production in host cells to circumnavigate miRNA-mediated innate immunity by targeting proteins involved in the RNA interference pathway (e.g., DICER) $(18,22$, 26, 28, 31, 173) (Figure 3D). Given miRNAs mediate host response to infection, it follows that miRNA deregulation could contribute to susceptibility to disease and immunopathology. Studies relating miRNA expression to patient outcomes in infection are now needed to understand how deregulation of miRNAs can contribute to disease course. This could provide new therapeutic targets or prognostic indicators. 


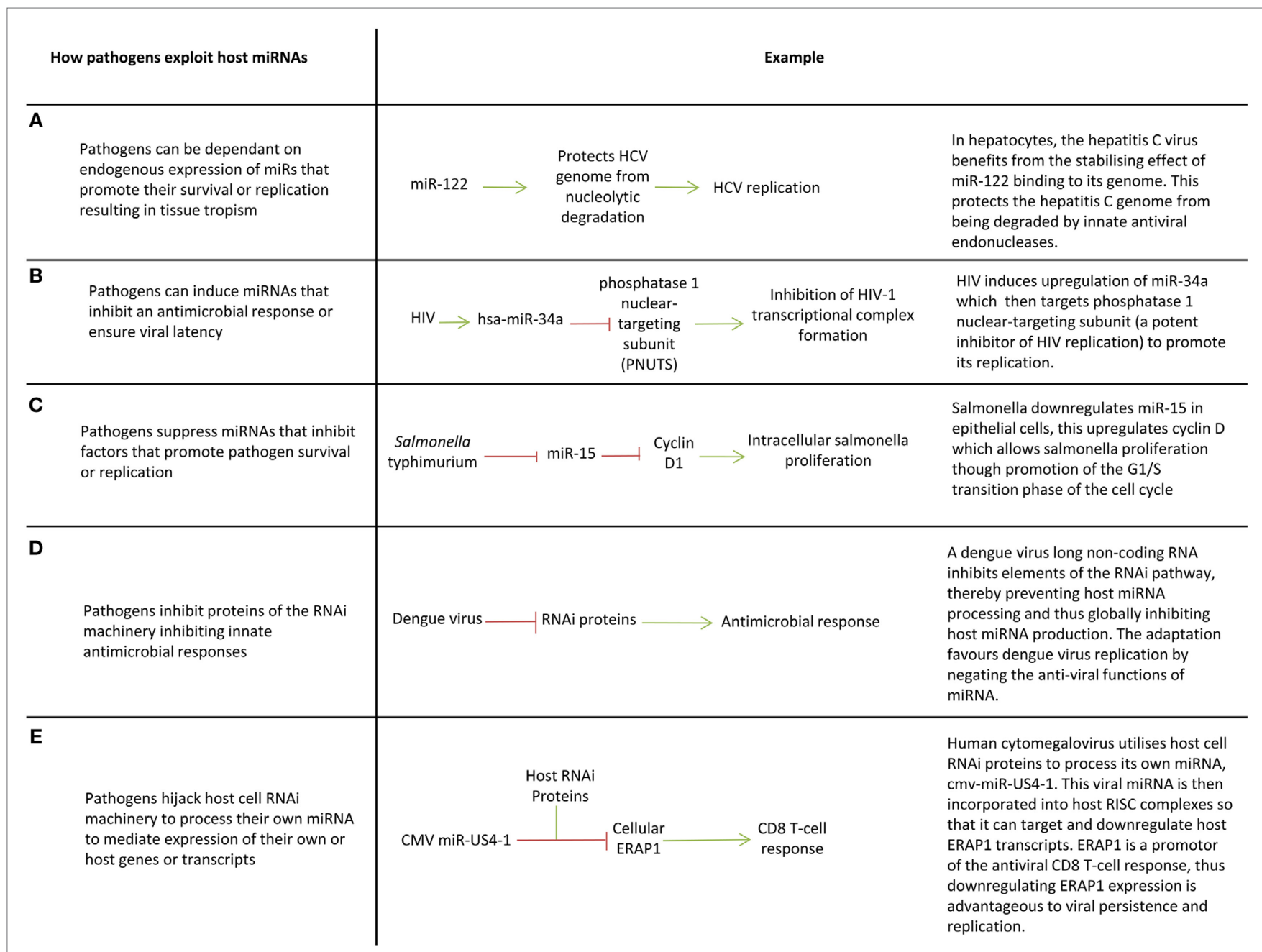

FIGURE 3 | Pathogen exploitation of host microRNAs (miRNAs) and miRNA processing pathways. (A-E) Key ways pathogens exploit host miRNAs.

Intracellular bacteria including Mycobacterium spp., Listeria monocytogenes, Francisella tularensis, and Salmonella enterica also appear to manipulate host cell miRNA expression to downregulate inflammatory cytokines and the factors and pathways that promote autophagy and cell apoptosis $(27,30,34,174)$. For example, miR-26a is downregulated in macrophages by Mycobacterium tuberculosis which leads to depression of the miR-26a target Krüpple-like factor 4 (KLF4). KLF4 is a transcription factor that skews macrophage polarization away from the inflammatory M1 phenotype toward an anti-inflammatory M2 in which bactericidal mechanisms are repressed. Downregulation of miR-26a in M. tuberculosis infected cells therefore promotes M2 polarization which facilitates M. tuberculosis survival (175). The molecular mechanisms whereby intracellular bacteria manipulate host cell miRNAs remains to be elucidated.

\section{VIRUSES HAVE miRNAs TOO}

Viruses encode miRNAs within in their genome which promote viral replication and control latency (96, 176-183). HIV,
Ebola, Adenoviridae, Herpesviridae, and the BK polyomavirus utilize host cell machinery to process their own miRNAs (96, 176-183) (Figure 3E). Viral miRNAs promote viral latency, prevent cell apoptosis (an oncogenic feature of oncoviruses such as Kaposi's sarcoma-associated herpes virus that promotes malignant transformation), and downregulate factors which promote an inflammatory response and recruitment of leukocytes (184). The HSV-1 gene latency-associated transcript, for example, encodes miR-H2-3p which is cotranscribed with, and targets a viral immediate-early transcriptional activator (ICPO) believed to promote $\mathrm{HSV}-1$ replication and reactivation from latency (183). CMV inhibits CD8(+) T-cell responses by expressing miRUS4-1 which targets endoplasmic aminopeptidase 1 , a protein responsible for trimming peptides for presentation by $\mathrm{MHC}$ class I molecules (179). The Kaposi's sarcoma-associated virus expresses many miRNAs including miR-K5 and miR-K9 which target MYD88 and IRAK1 to reduce inflammatory cytokine expression and clearance by the immune system (19). Viral miRNAs may mimic host miRNAs, e.g., Ebola virus and the Kaposi's sarcoma-associated herpes virus encode miRNA orthologs of 
miR-155 (180, 185). In the case of Ebola, this miRNA-155 analog targets importin- $\alpha 5$ (KPNA1) expression which may lead to dysfunction of the interferon signaling and an unbalanced immune response thereby contributing to the marked pathogenicity of the virus (180). Manipulating viral miRNAs using miRNA mimics or antagomiRs could hold therapeutic potential. Several studies show viral miRNAs are excreted in exosomes of infected cells, and in some cases this appears to modulate innate immune responses in recipient cells including dendritic cells and macrophages; however, the functional significance of this remains to be seen (186-190).

There is little evidence that bacteria have miRNAs. Deep sequencing of a mouse macrophage cell line (RAW264.7) infected with Mycobacterium marinum identified a 23nt RNA molecule which is predicted to arise from a stem loop, and was not present in broth grown bacteria, prompting the authors to suggest DICER in the host cell is required for processing as would be expected for a miRNA (191). Evidence is far from conclusive however and deep sequencing of human cells infected with Chlamydia trachomatis, Legionella pneumophila, and M. tuberculosis in the same study did not identify any potential bacterial miRNAs.

\section{THE CLINICAL APPLICATIONS OF miRNAs: TREATMENTS}

A promising application of miRNAs is to utilize their immunomodulatory functions to promote antimicrobial pathways during infection and control dysregulated inflammatory responses during sepsis. Hock et al., noted physiological downregulation of miR-328-3p in the lungs of mice infected with non-typeable Haemophilus influenza promoted phagocytosis by neutrophils and macrophages and bacterial killing and found boosting this downregulation by intra-tracheally administering an antagomiR (see Box 1) of miR-328-3p enhanced bacterial killing when mice were challenged with non-typeable $H$. influenza. Alexander et al. observed that administration of exosomes containing miR-146a and miR-155 ameliorated and enhanced mice inflammatory response to endotoxin in vivo, respectively, prompting the authors to speculate that such treatments could be useful adjuncts in managing sepsis (in the case of miR-146a) or vaccination (in the case of miR-155). Work by Wang et al. supports the notion that miRNA therapies could be a useful treatment in sepsis after they discovered administration of mesenchymal stem cell exosomes containing miR-223 confer cardiac protection in septic mice (192).

A miRNA-based strategy that renders the host resistant to the exploitation of their miRNAs by pathogens opens up a new avenue of therapeutics. As noted above, EV-71 infection induces miRNA-146a in cells to prevent an innate immune response. Work by Ho et al. showed that inhibition of miR-146a in EV-71 infected mice using an intraperitoneal injection of a miR-146a antagomiR significantly improved survival from 25 to $80 \%$ by reinstating an interferon gamma response (83). Bacterial infections may also be treatable with miRNAs. Upregulation of miR-128 by S. enterica promoted $S$. enterica survival in mice and intragastric delivery of anti-miR-128 reverses this phenomenon in mice and suppressed S. enterica infection (193).
Translation of these concepts to clinical treatments is on the horizon. An oligonucleotide inhibitor of miR-122 called Miravirsen was shown to be proven to be safe and well tolerated in HCV-infected patients in a phase IIa trial (194). In an effort to target drug delivery more effectively RG-101 was created in which the oligonucleotide inhibitor is conjugated to a high affinity ligand for the hepatocyte-specific asialoglycoprotein receptor (ASGPR). A recent phase $1 \mathrm{~b}$ double blind randomized controlled trial of RG-101 showed a single subcutaneous dose induced a significant reduction in viral load in patients with HCV within 4 weeks of treatment (195). Unfortunately, viral rebound was seen in most patients (22 out of 28) and this was associated with HCV 5 'UTR mutations. A small number of patients (3 out 28) had a sustained antiviral response at 76 weeks and phase II trials are planned to see whether combining RG-101 with virus targeting antiviral agents augments HCV therapy. Interestingly RG-101 appeared to increase NK-cell frequency and reduce activation which may have contributed to control of HCV (196). The hope is a treatment like RG-101 could shorten current HCV treatment regimens or offer an alternative treatment option in patients who have not responded to standard therapies (195).

Overall, using miRNA-based therapies to leverage immune response may prove useful adjuncts to standard antimicrobial therapies, e.g., in multidrug resistant gram-negative infections, or chronic viral infections such as hepatitis C. Nevertheless, there are significant challenges to implementing miRNA-based antimicrobial therapeutics which include devising methods of administration and drug design that will protect miRNA mimics/ antagomiRs from circulating RNAse enzymes. Delivery systems have to ensure targeted efficient delivery of miRNAs to the site of infection, because, as noted above, a miRNA may appear in many cell types, serving very different functions making off target effects a real possibility, limiting efficacy and safety (134). A detailed analysis of the outcomes of phase 1 trials of two miRNA-based cancer treatments will provide more important data on the feasibility of miRNA-based therapeutics generally $(197,198)$. As noted in the RG-101 trial above, viral mutation and resistance is an issue that will need tackling (195).

\section{THE CLINICAL APPLICATIONS OF miRNAS: BIOMARKERS OF INFECTIOUS DISEASE}

Extracellular miRNAs are ideal biomarker candidates because they can be isolated from biological fluids (199). RT-PCR is already used routinely in the clinical setting to quickly identify infections (e.g., respiratory infections in babies with bronchiolitis) and could be used to quantify ex-miRNAs in patient samples.

A comprehensive search of the literature identified 57 studies assessing ex-miRNAs in infectious diseases through whole micronome profiling and candidate miRNA approaches (see Tables S2 and S3 in Supplementary Material). The overwhelming majority of these studies are serum and plasma based, but ex-miRNAs in CSF, saliva and sputum have also been investigated. Most studies, to date, have focused on HCV, HBV, HIV, tuberculosis (TB), and sepsis and aim to improve diagnosis and prognosticate infection 
outcome (e.g., death in sepsis, liver cirrhosis in hepatitis) or treatment response.

Most infection studies compare the ex-miRNA profile of patients with healthy controls. Many identify ex-miRNA signatures which are highly predictive of infection. Zhang et al. found the combined expression of miR-378, miR-483-5p, miR-22, miR29c, miR-101, and miR-320b could differentiate pulmonary TB from healthy controls with sensitivity and specificity of 95 and $91.8 \%$, respectively (200). The issue with using healthy controls as a comparator group is that differentially expressed ex-miRNAs may represent a non-specific marker of infection; this limits the clinical translatability of these studies given most people undergoing tests are symptomatic of some disease process.

A handful of studies have chosen more pragmatic comparator groups and promisingly suggest ex-miRNA signatures can differentiate particular infectious disease from other differential diagnoses. Zhang et al. found miR-379, 483-5p, 23, 29c were upregulated, and miRNA 102 and 320b were downregulated in the serum of patients with pulmonary TB compared to patients with pneumonia, lung cancer, and COPD and this was confirmed in a second independent cohort (200). Interesting data from investigators in China identified miRNA signatures which differentiate enteroviral hand foot and mouth, coxsackie hand foot and mouth, pertussis, TB, and varicella from each other $(100,201)$.

A promising application of ex-miRNA biomarker work may be to differentiate viral from bacterial infection, identify or prognosticate sepsis, and in monitoring of response to antimicrobial treatment. At least 13 studies investigating ex-miRNA signatures in sepsis have been published; most are conducted in an intensive care unit (ICU) setting. In more than one study, miR-223, miR-193, miR-483, miR-499, miR-15a/b, and miR-16 have been identified as potential biomarkers of sepsis diagnosis and mortality (see Tables S2 and S3 in Supplementary Material). There are substantial inter-study discrepancies in miRNAs identified as potential biomarkers; this may be due heterogeneity in study design (e.g., data normalization methods) and confounders such as hospital differences in defining sepsis and ICU admission criteria. Differences in the lengths of illness between patients creates noise in the data; longitudinal studies that measure serial miRNA levels would provide temporal information on miRNA expression in sepsis and may resolve some conflicting findings.

The most commonly identified biomarker across all exmiRNA biomarkers of infection studies is miR-122 because of the over-representation of hepatitis studies in ex-miRNA biomarker studies. Studies of hepatitis C and hepatitis B have repeatedly found an association between circulating miR-122 and an aspect of infection (202-204). miR-122 is highly expressed by hepatocytes, and the association between levels of serum miR-122 and hepatitis may be the result of hepatocyte death. Upregulation of serum miR-122 is associated with HCV and HBV infection per se, correlates with viral DNA titers and falls during antiviral treatment (202-204). Conflicting evidence exists regarding the use of baseline miR-122 to prognosticate likelihood of response to treatment and liver cirrhosis (202-205). Among the 30 biomarker studies which used a miRNA profiling method (rather than a candidate miRNA approach which are at risk of heavy reporting bias), the most commonly identified ex-miRNAs biomarkers were miR-122 and the miR-29 family (identified in 7 studies), miR-21 and miR-146 (identified in 4 studies), and miR-150, miR16, miR-22, miR-125, miR-134, miR-194, and miR-106 (identified in 3 studies). Given the significant heterogeneity across all studies, there are significant limitations in combining them in this way, nevertheless it is interesting to note that a several of these miRNAs (miR-125, miR-150, and miR-21) already have established roles in lymphocyte development and activation $(54,56)$.

There are challenges in using miRNAs as biomarkers of infectious disease, however, and this is underlined by a lack of inter-study cross validation of many results. Conflicting study results may arise from heterogeneity in study design including differences in populations and control groups; methods of miRNA extraction and the circulating fraction under investigation (serum, plasma, microvesicles, or exosomes); micronome expression profiling platforms (next generation sequencing, probe-based hybridization microarrays, or RT-PCR arrays) and the dearth of miRNAs assessed; the limited statistical power of many studies at the profiling stage; data normalization methods; whether p-values were adjusted to take account of multiple testing issues (usually not done); and whether confirmatory cohorts were used to validate results. Given there is good evidence that miRNA contained in exosomes is functionally secreted as intercellular mediators of gene regulation, it is tempting to speculate that biomarker studies which profile miRNAs in exosomes rather than ex-miRNA in total plasma/serum (which will include a background of miRNA present from dead cells) could be more sensitive or specific biomarkers; comparisons of different extraction methods within the same biomarker study could help resolve this possibility.

\section{THE CLINICAL APPLICATIONS OF miRNAs: IMPROVING VACCINES}

As previously discussed, miRNAs may inhibit viruses through direct targeting of viral genomes or transcripts. This concept is being exploited to create new and attenuated vaccines by incorporating miRNA response elements (miRNA target sequences) into viral vaccine genomes. When the virus enters a cell-type which expresses the miRNA which targets the miRNA response elements (MRE), the virus is attenuated. The virus is not attenuated in other cells not expressing that miRNA. In theory, this allows the creation of live vaccines which are attenuated in a tissue specific manner, maximizing efficacy while minimizing harm (see Figure 4).

Several groups have demonstrated safe, efficacious vaccination in mice through the incorporation of MREs into viral genomes. Perez et al. incorporated the ubiquitously expressed miR-93 MRE into a live influenza virus and showed the vaccine was safe and effective in mice (206). Most groups use MREs that correspond to tissue-specific miRNAs; an example being the incorporation of miR-124 in polio, West Nile, and Dengue viruses to selectively prevent replication in neuronal cells; and the incorporation of a let-7 MREs in $\mathrm{H} 1 \mathrm{~N} 1$ viral vaccines to reduce replication in bronchial cells $(152,207-210)$. In all of these cases, vaccination was efficacious and viruses were significantly attenuated. In two 


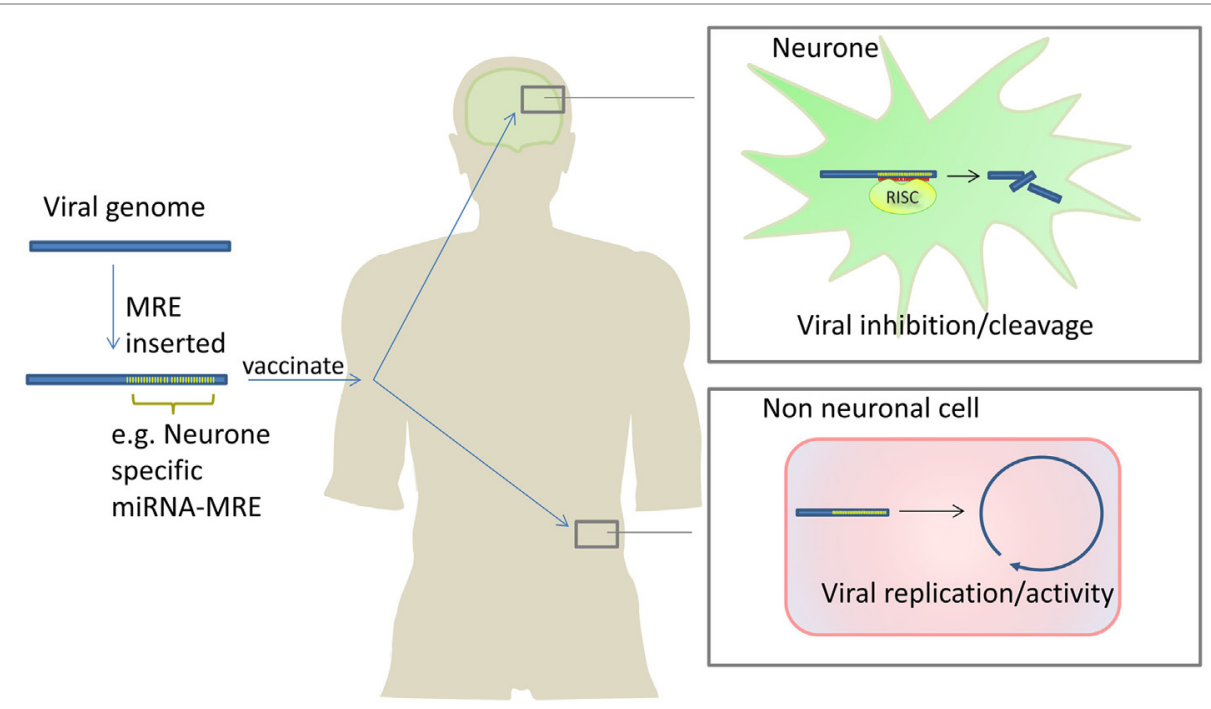

FIGURE 4 | Attenuating live viral vaccines by inclusion of microRNA response elements (MREs). Insertion of MREs in a viral genome can make viral vaccines safer because the virus is unable to replicate in cells which express the miRNAs which bind to the inserted MREs. In this example, a neurone-specific miRNA MRE is inserted into a virus which attacks the nervous system. The cognate miRNA is expressed in neurones inhibiting viral replication/activity. In non-neuronal cells, the miRNA is not expressed therefore the virus is able to replicate and infect cells stimulating robust immunity. Barnes et al. have used this approach to develop an attenuated polio vaccine in mice (152).

studies, a small number of immunocompromised mice succumbed to infection, and this was due to MRE mutation $(152,153)$. Increasing the number of MREs repeats, adding MREs at different sites, incorporating multiple, different MREs in the viral genome, or combining MREs with other genome alterations that attenuate viruses has been shown to ameliorate this $(153,211)$.

MicroRNA could also be used as adjuvants to regulate proteins which could inhibit vaccine response. Protein kinase R-like endoplasmic reticulum kinase (PERK) triggers apoptosis in response to viral infection which can inhibit DNA vaccines from working. Wheatley et al. developed a plasmid-based HIV vaccine which expressed HIV-1 envelope (Env) antigens as well as a miRNA designed to inhibit PERK (an in silico designed miRNA named miR-huPERK) (212). To make this plasmid the sequence encoding miR-huPERK inserted into the miR-155 gene (the mature miR-155 sequence was removed but the rest of the pri-miR-155 sequence remained) and then cloned into the plasmid along with Env. Transfecting cell lines with this plasmid reduced PERK expression only when the mir-155 gene was used as a scaffold for miR-huPERK. Vaccinating BALB/c mice with this modified DNA vaccine augmented Env-specific CD8+ T-cell immunity. The study provides proof of principle that incorporation of miRNAs into vaccine constructs can ameliorate innate antiviral pathways which usually limit maximal antigen expression; the result is enhanced immunogenicity of DNA vaccines; potentially enabling development of novel DNA vaccines (212).

\section{CONCLUSION}

MicroRNAs are essential mediators of host response to pathogens. They have pleiotropic roles which microbes have evolved to exploit. Elucidating the roles miRNAs in host response to infectious disease is inherently interesting at it provides a tool for identifying key genes and pathways that must be activated, enhanced, repressed, or silenced to facilitate an effective immune response. The complex regulatory network within which miRNAs are embedded, make unpicking the roles of miRNAs tough but not impossible. Integrating large miRNA and mRNA datasets using advanced statistical techniques (in a "systems biology" approach) will facilitate the unpicking of these complex networks.

Clinical applications of miRNAs are on the horizon. The novel anti-miRNA treatment miravirsen is already in phase $2 b$ trials suggesting miRNA-based treatments may well become a reality; viral vaccines attenuated through incorporation of miRNA target sequences are at the preclinical stage; and miRNA biomarkers of infection hold promise. In all cases however there are challenges that must be overcome. miRNAs have multiple targets and therefore any vaccines or treatments that harness miRNAs may produce off-target effects compromising safety. In the context of ex-miRNA biomarkers identification of universal endogenous controls are needed to improve cross study reproducibility of findings, and a more standardized approach to biomarker studies may also help. Initiatives devoted to harnessing the diagnostic and therapeutic potential of extracellular RNAs like The National Institute for Health Extracellular Communication Consortium can facilitate this (213).

As the literature on miRNAs grows, the potential for new miRNA therapeutics, diagnostics/prognostics, and vaccines becomes tangibly closer. Translating the insights of miRNA studies into improving the lives of patients is the critical next step. 


\section{AUTHOR CONTRIBUTIONS}

RD conceptualized, researched, and wrote the manuscript. DO reviewed the manuscript and made substantial contributions to the drafting process. AP conceptualized, reviewed the manuscript, and made substantial contributions to the drafting process.

\section{ACKNOWLEDGMENTS}

Supported by the NIHR Biomedical Research Centre, based at Oxford University Hospitals Trust, Oxford. The views expressed are those of the author(s) and not necessarily those of the NHS, the NIHR or the Department of Health.

\section{REFERENCES}

1. Lee RC, Feinbaum RL, Ambros V. The C. elegans heterochronic gene lin-4 encodes small RNAs with antisense complementarity to lin-14. Cell (1993) 75:843-54. doi:10.1016/0092-8674(93)90529-Y

2. He L, Hannon GJ. MicroRNAs: small RNAs with a big role in gene regulation. Nat Rev Genet (2004) 5:522-31. doi:10.1038/nrg1379

3. Bartel DP. MicroRNAs: genomics, biogenesis, mechanism, and function. Cell (2004) 116:281-97. doi:10.1016/S0092-8674(04)00045-5

4. miRbase. miRbase Version 21. (2017). Available from: http://www.mirbase.org/

5. Friedman RC, Farh KK-H, Burge CB, Bartel DP. Most mammalian mRNAs are conserved targets of microRNAs. Genome Res (2009) 19:92-105. doi:10.1101/gr.082701.108

6. Bazzoni F, Rossato M, Fabbri M, Gaudiosi D, Mirolo M, Mori L, et al. Induction and regulatory function of miR-9 in human monocytes and neutrophils exposed to proinflammatory signals. Proc Natl Acad Sci U S A (2009) 106:5282-7. doi:10.1073/pnas.0810909106

7. Chen C-Z, Li L, Lodish HF, Bartel DP. MicroRNAs modulate hematopoietic lineage differentiation. Science (2004) 303:83-6. doi:10.1126/science. 1091903

8. Cobb BS, Nesterova TB, Thompson E, Hertweck A, O'Connor E, Godwin J, et al. $\mathrm{T}$ cell lineage choice and differentiation in the absence of the RNase III enzyme Dicer. J Exp Med (2005) 201:1367-73. doi:10.1084/jem.20050572

9. Curtale G, Mirolo M, Renzi TA, Rossato M, Bazzoni F, Locati M. Negative regulation of toll-like receptor 4 signaling by IL-10-dependent microRNA-146b. Proc Natl Acad Sci U S A (2013) 110:11499-504. doi:10.1073/ pnas. 1219852110

10. Koralov SB, Muljo SA, Galler GR, Krek A, Chakraborty T, Kanellopoulou C, et al. Dicer ablation affects antibody diversity and cell survival in the B lymphocyte lineage. Cell (2008) 132:860-74. doi:10.1016/j.cell.2008.02.020

11. Mehta A, Baltimore D. MicroRNAs as regulatory elements in immune system logic. Nat Rev Immunol (2016) 16:279-94. doi:10.1038/nri.2016.40

12. Ni F, Guo C, Sun R, Fu B, Yang Y, Wu L, et al. MicroRNA transcriptomes of distinct human NK cell populations identify miR-362-5p as an essential regulator of NK cell function. Sci Rep (2015) 5:9993. doi:10.1038/ srep09993

13. Rossato M, Curtale G, Tamassia N, Castellucci M, Mori L, Gasperini S, et al. IL-10-induced microRNA-187 negatively regulates TNF- $\alpha$, IL-6, and IL-12p40 production in TLR4-stimulated monocytes. Proc Natl Acad Sci U S A (2012) 109:E3101-10. doi:10.1073/pnas.1209100109

14. Smyth LA, Boardman DA, Tung SL, Lechler R, Lombardi G. MicroRNAs affect dendritic cell function and phenotype. Immunology (2015) 144: 197-205. doi:10.1111/imm.12390

15. Steiner DF, Thomas MF, Hu JK, Yang Z, Babiarz JE, Allen CDC, et al. MicroRNA-29 regulates T-box transcription factors and interferon- $\gamma$ production in helper T cells. Immunity (2011) 35:169-81. doi:10.1016/j. immuni.2011.07.009

16. Bandyopadhyay S, Friedman RC, Marquez RT, Keck K, Kong B, Icardi MS, et al. Hepatitis $\mathrm{C}$ virus infection and hepatic stellate cell activation downregulate miR-29: miR-29 overexpression reduces hepatitis $\mathrm{C}$ viral abundance in culture. J Infect Dis (2011) 203:1753-62. doi:10.1093/infdis/jir186

\section{FUNDING}

This work was financially supported by a career development fellowship awarded to RD by the NIHR Oxford Biomedical Research Centre and a NIHR Oxford Biomedical Research Centre (BRC) Principal Fellow Award, awarded to awarded to AP. The funders had no role in the decision to publish or preparation of the manuscript.

\section{SUPPLEMENTARY MATERIAL}

The Supplementary Material for this article can be found online at http://journal.frontiersin.org/article/10.3389/fimmu.2017.01182/ full\#supplementary-material.

17. Cameron JE, Yin Q, Fewell C, Lacey M, McBride J, Wang X, et al. EpsteinBarr virus latent membrane protein 1 induces cellular microRNA miR-146a a modulator of lymphocyte signaling pathways. J Virol (2008) 82:1946-58. doi:10.1128/JVI.02136-07

18. Chinnappan M, Singh AK, Kakumani PK, Kumar G, Rooge SB, Kumari A, et al. Key elements of the RNAi pathway are regulated by hepatitis B virus replication and $\mathrm{HBx}$ acts as a viral suppressor of RNA silencing. Biochem $J$ (2014) 462:347-58. doi:10.1042/BJ20140316

19. Cullen BR. MicroRNAs as mediators of viral evasion of the immune system. Nat Immunol (2013) 14:205-10. doi:10.1038/ni.2537

20. Ellis-Connell AL, Iempridee T, Xu I, Mertz JE. Cellular microRNAs 200b and 429 regulate the Epstein-Barr virus switch between latency and lytic replication. J Virol (2010) 84:10329-43. doi:10.1128/JVI.00923-10

21. Fu Y-R, Liu X-J, Li X-J, Shen Z, Yang B, Wu C-C, et al. MicroRNA miR-21 attenuates human cytomegalovirus replication in neural cells by targeting Cdc25a. J Virol (2015) 89:1070-82. doi:10.1128/JVI.01740-14

22. Grinberg M, Gilad S, Meiri E, Levy A, Isakov O, Ronen R, et al. Vaccinia virus infection suppresses the cell microRNA machinery. Arch Virol (2012) 157:1719-27. doi:10.1007/s00705-012-1366-z

23. Jopling CL, Yi M, Lancaster AM, Lemon SM, Sarnow P. Modulation of hepatitis C virus RNA abundance by a liver-specific microRNA. Science (2005) 309:1577-81. doi:10.1126/science.1113329

24. Li J, Yu L, Shen Z, Li Y, Chen B, Wei W, et al. miR-34a and its novel target, NLRC5, are associated with HPV16 persistence. Infect Genet Evol (2016) 44:293-9. doi:10.1016/j.meegid.2016.07.013

25. Lui YLEY, Tan TLT, Woo WH, Timms P, Hafner LML, Tan KKH, et al. Enterovirus71 (EV71) utilise host microRNAs to mediate host immune system enhancing survival during infection. PLoS One (2014) 9:e102997. doi:10.1371/journal.pone.0102997

26. Mansouri S, Pan Q, Blencowe BJ, Claycomb JM, Frappier L. Epstein-Barr virus EBNA1 protein regulates viral latency through effects on let-7 microRNA and dicer. J Virol (2014) 88:11166-77. doi:10.1128/JVI.01785-14

27. Maudet C, Mano M, Sunkavalli U, Sharan M, Giacca M, Förstner KU, et al. Functional high-throughput screening identifies the miR-15 microRNA family as cellular restriction factors for Salmonella infection. Nat Commun (2014) 5:4718. doi:10.1038/ncomms5718

28. Moon SL, Dodd BJT, Brackney DE, Wilusz CJ, Ebel GD, Wilusz J. Flavivirus sfRNA suppresses antiviral RNA interference in cultured cells and mosquitoes and directly interacts with the RNAi machinery. Virology (2015) 485:322-9. doi:10.1016/j.virol.2015.08.009

29. Mukherjee A, Shrivastava S, Bhanja Chowdhury J, Ray RBR, Ray RBR. Transcriptional suppression of miR-181c by hepatitis C virus enhances homeobox A1 expression. J Virol (2014) 88:7929-40. doi:10.1128/ JVI.00787-14

30. Ni B, Rajaram MVS, Lafuse WP, Landes MB, Schlesinger LS. Mycobacterium tuberculosis decreases human macrophage IFN- $\gamma$ responsiveness through miR-132 and miR-26a. J Immunol (2014) 193:4537-47. doi:10.4049/ jimmunol.1400124

31. Sanghvi VR, Steel LF. A re-examination of global suppression of RNA interference by HIV-1. PLoS One (2011) 6:e17246. doi:10.1371/journal pone.0017246 
32. Tang W-F, Huang R-T, Chien K-Y, Huang J-Y, Lau K-S, Jheng J-R, et al. Host microRNA miR-197 plays a negative regulatory role in the enterovirus 71 infectious cycle by targeting the RAN protein. J Virol (2016) 90:1424-38. doi:10.1128/JVI.02143-15

33. Wang Y, Jiang L, Ji X, Yang B, Zhang Y, Fu X-D. Hepatitis B viral RNA directly mediates down-regulation of the tumor suppressor microRNA miR-15a/ miR-16-1 in hepatocytes. J Biol Chem (2013) 288:18484-93. doi:10.1074/jbc. M113.458158

34. Zhou R, Gong A-Y, Chen D, Miller RE, Eischeid AN, Chen X-M. Histone deacetylases and NF-kB signaling coordinate expression of CX3CL1 in epithelial cells in response to microbial challenge by suppressing miR-424 and miR-503. PLoS One (2013) 8:e65153. doi:10.1371/journal.pone.0065153

35. Cullen BR. Transcription and processing of human microRNA precursors. Mol Cell (2004) 16:861-5. doi:10.1016/j.molcel.2004.12.002

36. Ha M, Kim VN. Regulation of microRNA biogenesis. Nat Rev Mol Cell Biol (2014) 15:509-24. doi:10.1038/nrm3838

37. Lee Y, Jeon K, Lee J-T, Kim S, Kim VN. MicroRNA maturation: stepwise processing and subcellular localization. EMBO J (2002) 21:4663-70. doi:10.1093/emboj/cdf476

38. Lee Y, Kim M, Han J, Yeom K-H, Lee S, Baek SH, et al. MicroRNA genes are transcribed by RNA polymerase II. EMBO J (2004) 23:4051-60. doi:10.1038/ sj.emboj.7600385

39. Schamberger A, Sarkadi B, Orban TI. Human mirtrons can express functional microRNAs simultaneously from both arms in a flanking exon-independent manner. RNA Biol (2012) 9:1177-85. doi:10.4161/rna.21359

40. Lewis BP, Shih IH, Jones-Rhoades MW, Bartel DP, Burge CB. Prediction of mammalian microRNA targets. Cell (2003) 115:787-98. doi:10.1016/ S0092-8674(03)01018-3

41. Krek A, Grün D, Poy MN, Wolf R, Rosenberg L, Epstein EJ, et al. Combinatorial microRNA target predictions. Nat Genet (2005) 37:495-500. doi:10.1038/ng1536

42. Fang Z, Rajewsky N. The impact of miRNA target sites in coding sequences and in 3'UTRs. PLoS One (2011) 6:e18067. doi:10.1371/journal.pone.0018067

43. Lin C-C, Liu L-Z, Addison JB, Wonderlin WF, Ivanov AV, Ruppert JM. A KLF4-miRNA-206 autoregulatory feedback loop can promote or inhibit protein translation depending upon cell context. Mol Cell Biol (2011) 31:2513-27. doi:10.1128/MCB.01189-10

44. Lytle JR, Yario TA, Steitz JA. Target mRNAs are repressed as efficiently by microRNA-binding sites in the 5' UTR as in the 3' UTR. Proc Natl Acad Sci US A (2007) 104:9667-72. doi:10.1073/pnas.0703820104

45. Place RF, Li L-C, Pookot D, Noonan EJ, Dahiya R. MicroRNA-373 induces expression of genes with complementary promoter sequences. Proc Natl Acad Sci U S A (2008) 105:1608-13. doi:10.1073/pnas.0707594105

46. Vasudevan S, Tong Y, Steitz JA. Switching from repression to activation: microRNAs can up-regulate translation. Science (2007) 318:1931-4. doi:10.1126/science.1149460

47. Zhou H, Rigoutsos I. miR-103a-3p targets the 5' UTR of GPRC5A in pancreatic cells. RNA (2014) 20:1431-9. doi:10.1261/rna.045757.114

48. Jonas S, Izaurralde E. Towards a molecular understanding of microRNAmediated gene silencing. Nat Rev Genet (2015) 16:421-33. doi:10.1038/nrg3965

49. Bhattacharyya SN, Habermacher R, Martine U, Closs EI, Filipowicz W. Relief of microRNA-mediated translational repression in human cells subjected to stress. Cell (2006) 125:1111-24. doi:10.1016/j.cell.2006.04.031

50. Carthew RW, Sontheimer EJ. Origins and mechanisms of miRNAs and siRNAs. Cell (2009) 136:642-55. doi:10.1016/j.cell.2009.01.035

51. Ebert MS, Sharp PA. Roles for microRNAs in conferring robustness to biological processes. Cell (2012) 149:515-24. doi:10.1016/j.cell.2012.04.005

52. Neilson JR, Zheng GXY, Burge CB, Sharp PA. Dynamic regulation of miRNA expression in ordered stages of cellular development. Genes Dev (2007) 21:578-89. doi:10.1101/gad.1522907

53. Rupp LJ, Brady BL, Carpenter AC, De Obaldia ME, Bhandoola A, Bosselut R, et al. The microRNA biogenesis machinery modulates lineage commitment during $\alpha \beta$ T cell development. J Immunol (2014) 193:4032-42. doi:10.4049/ jimmunol.1401359

54. Rossi RL, Rossetti G, Wenandy L, Curti S, Ripamonti A, Bonnal RJP, et al. Distinct microRNA signatures in human lymphocyte subsets and enforcement of the naive state in CD4+ T cells by the microRNA miR-125b. Nat Immunol (2011) 12:796-803. doi:10.1038/ni.2057
55. Baumjohann D, Ansel KM. MicroRNA-mediated regulation of T helper cell differentiation and plasticity. Nat Rev Immunol (2013) 13:666-78. doi:10.1038/nri3494

56. Li J, Wan Y, Ji Q, Fang Y, Wu Y. The role of microRNAs in B-cell development and function. Cell Mol Immunol (2013) 10:107-12. doi:10.1038/cmi. 2012.62

57. Gupta P, Liu B, Wu JQ, Soriano V, Vispo E, Carroll AP, et al. Genome-wide mRNA and miRNA analysis of peripheral blood mononuclear cells (PBMC) reveals different miRNAs regulating HIV/HCV co-infection. Virology (2014) 45(0-451):336-49. doi:10.1016/j.virol.2013.12.026

58. Lemaire J, Mkannez G, Guerfali FZ, Gustin C, Attia H, Sghaier RM, et al. MicroRNA expression profile in human macrophages in response to Leishmania major infection. PLoS Negl Trop Dis (2013) 7:e2478. doi:10.1371/ journal.pntd.0002478

59. Makkoch J, Poomipak W, Saengchoowong S, Khongnomnan K, Praianantathavorn K, Jinato T, et al. Human microRNAs profiling in response to influenza A viruses (subtypes pH1N1, H3N2, and H5N1). Exp Biol Med (Maywood) (2016) 241:409-20. doi:10.1177/1535370215611764

60. Muhammad SA, Fatima N, Syed N-I-H, Wu X, Yang XF, Chen JY. MicroRNA expression profiling of human respiratory epithelium affected by invasive Candida infection. PLoS One (2015) 10:e0136454. doi:10.1371/journal. pone. 0136454

61. Qi Y, Cui LLLL, Ge Y, Shi Z, Zhao K, Guo X, et al. Altered serum microRNAs as biomarkers for the early diagnosis of pulmonary tuberculosis infection. BMC Infect Dis (2012) 12:384. doi:10.1186/1471-2334-12-384

62. Wang C, Yang S, Sun G, Tang X, Lu S, Neyrolles O, et al. Comparative miRNA expression profiles in individuals with latent and active tuberculosis. PLoS One (2011) 6:e25832. doi:10.1371/journal.pone.0025832

63. Banerjee A, Schambach F, DeJong CS, Hammond SM, Reiner SL. MicroRNA-155 inhibits IFN-gamma signaling in CD4+ T cells. Eur J Immunol (2010) 40:225-31. doi:10.1002/eji.200939381

64. Bi J, Zeng X, Zhao L, Wei Q, Yu L, Wang X, et al. miR-181a induces macrophage polarized to M2 phenotype and promotes M2 macrophage-mediated tumor cell metastasis by targeting KLF6 and C/EBP $\alpha$. Mol Ther Nucleic Acids (2016) 5:e368. doi:10.1038/mtna.2016.71

65. de Yébenes VG, Belver L, Pisano DG, González S, Villasante A, Croce C, et al. miR-181b negatively regulates activation-induced cytidine deaminase in B cells. J Exp Med (2008) 205:2199-206. doi:10.1084/jem.20080579

66. Gong A-Y, Hu G, Zhou R, Liu J, Feng Y, Soukup GA, et al. MicroRNA-221 controls expression of intercellular adhesion molecule-1 in epithelial cells in response to Cryptosporidium parvum infection. Int J Parasitol (2011) 41:397-403. doi:10.1016/j.ijpara.2010.11.011

67. Kim SJ, Gregersen PK, Diamond B. Regulation of dendritic cell activation by microRNA let-7c and BLIMP1. J Clin Invest (2013) 123:823. doi:10.1172/ jci64712

68. Lam W-Y, Yeung AC-M, Ngai KL-K, Li M-S, To K-F, Tsui SK-W, et al. Effect of avian influenza A H5N1 infection on the expression of microRNA-141 in human respiratory epithelial cells. BMC Microbiol (2013) 13:104. doi:10.1186/1471-2180-13-104

69. Murata K, Yoshitomi H, Furu M, Ishikawa M, Shibuya H, Ito H, et al. MicroRNA-451 down-regulates neutrophil chemotaxis via p38 MAPK. Arthritis Rheumatol (2014) 66:549-59. doi:10.1002/art.38269

70. Nahid MA, Satoh M, Chan EKL. Interleukin 1 $\beta$-responsive microRNA-146a is critical for the cytokine-induced tolerance and cross-tolerance to toll-like receptor ligands. J Innate Immun (2015) 7:428-40. doi:10.1159/000371517

71. Teng Y, Miao J, Shen X, Yang X, Wang X, Ren L, et al. The modulation of miR-155 and miR-23a manipulates Klebsiella pneumoniae adhesion on human pulmonary epithelial cells via integrin $\alpha 5 \beta 1$ signaling. Sci Rep (2016) 6:31918. doi: $10.1038 /$ srep31918

72. Al-Qahtani AA, Al-Anazi MR, Nazir N, Wani K, Abdo AA, Sanai FM, et al. Association of single nucleotide polymorphisms in microRNAs with susceptibility to hepatitis B virus infection and HBV-related liver complications: a study in a Saudi Arabian population. J Viral Hepat (2017) 1-11. doi:10.1111/ jvh.12749

73. Cezar-de-Mello PFT, Toledo-Pinto TG, Marques CS, Arnez LEA, Cardoso CC, Guerreiro LTA, et al. Pre-miR-146a (rs2910164 G\&gt;C) single nucleotide polymorphism is genetically and functionally associated with leprosy. PLoS Negl Trop Dis (2014) 8:e3099. doi:10.1371/journal.pntd.0003099 
74. Cheong JY, Shin HD, Kim YJ, Cho SW. Association of polymorphism in microRNA 219-1 with clearance of hepatitis B virus infection. J Med Virol (2013) 85:808-14. doi:10.1002/jmv.23551

75. Misra MK, Mishra A, Pandey SK, Kapoor R, Sharma RK, Agrawal S. Genetic variation in micro-RNA genes of host genome affects clinical manifestation of symptomatic human cytomegalovirus infection. Hum Immunol (2015) 76:765-9. doi:10.1016/j.humimm.2015.09.035

76. Yu SJ, Kim J-W, Lee J-H, Yoon J-H, Lee H-S, Cheong JY, et al. Association of a microRNA-323b polymorphism with the persistence of hepatitis B virus infection by the enhancement of viral replication. J Viral Hepat (2014) 21:853-9. doi:10.1111/jvh.12215

77. Selvamani SP, Mishra R, Singh SK. Chikungunya virus exploits miR-146a to regulate NF- $\kappa$ B pathway in human synovial fibroblasts. PLoS One (2014) 9:e103624. doi:10.1371/journal.pone.0103624

78. Hook LM, Grey F, Grabski R, Tirabassi R, Doyle T, Hancock M, et al. Cytomegalovirus miRNAs target secretory pathway genes to facilitate formation of the virion assembly compartment and reduce cytokine secretion. Cell Host Microbe (2014) 15:363-73. doi:10.1016/j.chom.2014.02.004

79. Tong L, Lin L, Wu S, Guo Z, Wang T, Qin Y, et al. miR-10a* up-regulates coxsackievirus $\mathrm{B} 3$ biosynthesis by targeting the $3 \mathrm{D}$-coding sequence. Nucleic Acids Res (2013) 41:3760-71. doi:10.1093/nar/gkt058

80. Smith JL, Jeng S, McWeeney SK, Hirsch AJ. A microRNA screen identifies the Wnt signaling pathway as a regulator of the interferon response during flavivirus infection. J Virol (2017) 91:e2388-2316. doi:10.1128/JVI.02388-16

81. Duy J, Koehler JW, Honko AN, Schoepp RJ, Wauquier N, Gonzalez J-P, et al. Circulating microRNA profiles of Ebola virus infection. Sci Rep (2016) 6:24496. doi:10.1038/srep24496

82. Gao L, Ai J, Xie Z, Zhou C, Liu C, Zhang H, et al. Dynamic expression of viral and cellular microRNAs in infectious mononucleosis caused by primary Epstein-Barr virus infection in children. Virol J (2015) 12:208. doi:10.1186/ s12985-015-0441-y

83. Ho B-CC, Yu I-S, Lu L-F, Rudensky A, Chen H-Y, Tsai C-W, et al. Inhibition of miR-146a prevents enterovirus-induced death by restoring the production of type I interferon. Nat Commun (2014) 5:3344. doi:10.1038/ncomms4344

84. Shin OS, Kumar M, Yanagihara R, Song J-W. Hantaviruses induce cell typeand viral species-specific host microRNA expression signatures. Virology (2013) 446:217-24. doi:10.1016/j.virol.2013.07.036

85. Li J-F, Dai X-P, Zhang W, Sun S-H, Zeng Y, Zhao G-Y, et al. Upregulation of microRNA-146a by hepatitis B virus X protein contributes to hepatitis development by downregulating complement factor H. MBio (2015) 6:e2459-2414. doi:10.1128/mBio.02459-14

86. Luna JM, Scheel TKH, Danino T, Shaw KS, Mele A, Fak JJ, et al. Hepatitis C virus RNA functionally sequesters miR-122. Cell (2015) 160:1099-110. doi:10.1016/j.cell.2015.02.025

87. Pan D, Flores O, Umbach JL, Pesola JM, Bentley P, Rosato PC, et al. A neuron-specific host microRNA targets herpes simplex virus-1 ICP0 expression and promotes latency. Cell Host Microbe (2014) 15:446-56. doi:10.1016/j.chom.2014.03.004

88. Xu Z, Asahchop EL, Branton WG, Gelman BB, Power C, Hobman TC. MicroRNAs upregulated during HIV infection target peroxisome biogenesis factors: implications for virus biology, disease mechanisms and neuropathology. PLoS Pathog (2017) 13:e1006360. doi:10.1371/journal.ppat.1006360

89. Harden ME, Prasad N, Griffiths A, Munger K. Modulation of microRNAmRNA target pairs by human papillomavirus 16 oncoproteins. MBio (2017) 8:e2170-2116. doi:10.1128/mBio.02170-16

90. Chanda S, Nandi S, Chawla-Sarkar M. Rotavirus-induced miR-142-5p elicits proviral milieu by targeting non-canonical transforming growth factor beta signalling and apoptosis in cells. Cell Microbiol (2016) 18:733-47. doi: $10.1111 / \mathrm{cmi} .12544$

91. Bai XT, Nicot C. miR-28-3p is a cellular restriction factor that inhibits human T cell leukemia virus, type 1 (HTLV-1) replication and virus infection. J Biol Chem (2015) 290:5381-90. doi:10.1074/jbc.M114.626325

92. Tambyah PA, Sepramaniam S, Mohamed Ali J, Chai SC, Swaminathan P, Armugam A, et al. microRNAs in circulation are altered in response to influenza A virus infection in humans. PLoS One (2013) 8:e76811. doi:10.1371/ journal.pone.0076811

93. Zhu B, Ye J, Nie Y, Ashraf U, Zohaib A, Duan X, et al. MicroRNA-15b modulates Japanese encephalitis virus-mediated inflammation via targeting RNF125. J Immunol (2015) 195:2251-62. doi:10.4049/jimmunol.1500370
94. Lagos D, Pollara G, Henderson S, Gratrix F, Fabani M, Milne RSB, et al. miR-132 regulates antiviral innate immunity through suppression of the p300 transcriptional co-activator. Nat Cell Biol (2010) 12:513-9. doi:10.1038/ncb2054

95. Perwitasari O, Shim B-S, Jorquera PA, Kyriakis CS, Tripp RA, Wu W, et al. MicroRNA-555 has potent antiviral properties against poliovirus. J Gen Virol (2016) 97:659-68. doi:10.1099/jgv.0.000372

96. Broekema NM, Imperiale MJ. miRNA regulation of BK polyomavirus replication during early infection. Proc Natl Acad Sci U S A (2013) 110:8200-5. doi:10.1073/pnas.1301907110

97. Rocca A, Martelli F, Delbue S, Ferrante P, Bartolozzi D, Azzi A, et al. The JCPYV DNA load inversely correlates with the viral microRNA expression in blood and cerebrospinal fluid of patients at risk of PML. J Clin Virol (2015) 70:1-6. doi:10.1016/j.jcv.2015.06.104

98. Shi N, Zhang XY, Dong CY, Hou JL, Zhang ML, Guan ZH, et al. Alterations in microRNA expression profile in rabies virus-infected mouse neurons. Acta Virol (2014) 58:120-7. doi:10.4149/av_2014_02_120

99. Thornburg NJ, Hayward SL, Crowe JE. Respiratory syncytial virus regulates human microRNAs by using mechanisms involving beta interferon and NF-кB. MBio (2012) 3:e220-212. doi:10.1128/mBio.00220-12

100. Qi Y, Zhu Z, Shi Z, Ge Y, Zhao K, Zhou M, et al. Dysregulated microRNA expression in serum of non-vaccinated children with varicella. Viruses (2014) 6:1823-36. doi:10.3390/v6041823

101. Chugh PE, Damania BA, Dittmer DP. Toll-like receptor-3 is dispensable for the innate microRNA response to West Nile virus (WNV). PLoS One (2014) 9:e104770. doi:10.1371/journal.pone.0104770

102. Pylro VS, Oliveira FS, Morais DK, Cuadros-Orellana S, Pais FS-M, Medeiros JD, et al. ZIKV - CDB: a collaborative database to guide research linking SncRNAs and ZIKA virus disease symptoms. PLoS Negl Trop Dis (2016) 10:e0004817. doi:10.1371/journal.pntd.0004817

103. Budak F, Bal SH, Tezcan G, Guvenc F, Akalin EH, Goral G, et al. MicroRNA expression patterns of CD8+ T cells in acute and chronic brucellosis. PLoS One (2016) 11:e0165138. doi:10.1371/journal.pone. 0165138

104. Bandyopadhyay S, Long ME, Allen L-AH. Differential expression of microRNAs in Francisella tularensis-infected human macrophages: miR-155dependent downregulation of MyD88 inhibits the inflammatory response. PLoS One (2014) 9:e109525. doi:10.1371/journal.pone.0109525

105. Teng G, Wang W, Dai Y, Wang S, Chu Y, Li J. Let-7b is involved in the inflammation and immune responses associated with Helicobacter pylori infection by targeting toll-like receptor 4. PLoS One (2013) 8:e56709. doi:10.1371/ journal.pone.0056709

106. Tay HL, Kaiko GE, Plank M, Li J, Maltby S, Essilfie A-T, et al. Antagonism of miR-328 increases the antimicrobial function of macrophages and neutrophils and rapid clearance of non-typeable Haemophilus influenzae (NTHi) from infected lung. PLoS Pathog (2015) 11:e1004549. doi:10.1371/journal. ppat.1004549

107. Jorge KTOS, Souza RP, Assis MTA, Araújo MG, Locati M, Jesus AMR, et al. Characterization of microRNA expression profiles and identification of potential biomarkers in leprosy. J Clin Microbiol (2017) 55:1516-25. doi:10.1128/JCM.02408-16

108. Johnston DGW, Kearney J, Zasłona Z, Williams MA, O’Neill LAJ, Corr SC. MicroRNA-21 limits uptake of listeria monocytogenes by macrophages to reduce the intracellular niche and control infection. Front Cell Infect Microbiol (2017) 7:201. doi:10.3389/fcimb.2017.00201

109. Rothchild AC, Sissons JR, Shafiani S, Plaisier C, Min D, Mai D, et al miR-155-regulated molecular network orchestrates cell fate in the innate and adaptive immune response to Mycobacterium tuberculosis. Proc Natl Acad Sci U S A (2016) 113(41):E6172-81. doi:10.1073/pnas.1608255113

110. Liu M, John CM, Jarvis GA. Induction of endotoxin tolerance by pathogenic Neisseria is correlated with the inflammatory potential of lipooligosaccharides and regulated by microRNA-146a. J Immunol (2014) 192:1768-77. doi:10.4049/jimmunol.1301648

111. Ge Y, Zhao K, Qi Y, Min X, Shi Z, Qi X, et al. Serum microRNA expression profile as a biomarker for the diagnosis of pertussis. Mol Biol Rep (2013) 40:1325-32. doi:10.1007/s11033-012-2176-9

112. Jin T, Lu Y, He QX, Wang H, Li BF, Zhu LY, et al. The role of microRNA, miR24, and its target CHI3L1 in osteomyelitis caused by Staphylococcus aureus. J Cell Biochem (2015) 116:2804-13. doi:10.1002/jcb.25225

113. Tsai M-H, Chang C-H, Tsai R-K, Hong Y-R, Chuang T-H, Fan K-T, et al. Cross-regulation of proinflammatory cytokines by interleukin-10 and 
miR-155 in Orientia tsutsugamushi-infected human macrophages prevents cytokine storm. JInvest Dermatol (2016) 136:1398-407. doi:10.1016/j. jid.2015.11.034

114. Griss K, Bertrams W, Sittka-Stark A, Seidel K, Stielow C, Hippenstiel S, et al. MicroRNAs constitute a negative feedback loop in Streptococcus pneumoniae-induced macrophage activation. J Infect Dis (2016) 214:288-99. doi:10.1093/infdis/jiw109

115. Fang Y, Chen H, Hu Y, Li Q, Hu Z, Ma T, et al. Burkholderia pseudomalleiderived miR-3473 enhances NF- $\mathrm{KB}$ via targeting TRAF3 and is associated with different inflammatory responses compared to Burkholderia thailandensis in murine macrophages. BMC Microbiol (2016) 16:283. doi:10.1186/ s12866-016-0901-6

116. Dix A, Czakai K, Leonhardt I, Schäferhoff K, Bonin M, Guthke R, et al. Specific and novel microRNAs are regulated as response to fungal infection in human dendritic cells. Front Microbiol (2017) 8:270. doi:10.3389/fmicb.2017.00270

117. Yu L, Liao Q, Zeng X, Lv Z, Zheng H, Zhao Y, et al. MicroRNA expressions associated with eosinophilic meningitis caused by Angiostrongylus cantonensis infection in a mouse model. Eur J Clin Microbiol Infect Dis (2014) 33:1457-65. doi:10.1007/s10096-014-2087-x

118. Mantel P-Y, Hjelmqvist D, Walch M, Kharoubi-Hess S, Nilsson S, Ravel D, et al. Infected erythrocyte-derived extracellular vesicles alter vascular function via regulatory Ago2-miRNA complexes in malaria. Nat Commun (2016) 7:12727. doi:10.1038/ncomms12727

119. He X, Tang R, Sun Y, Wang Y-G, Zhen K-Y, Zhang D-M, et al. MicroR-146 blocks the activation of M1 macrophage by targeting signal transducer and activator of transcription 1 in hepatic schistosomiasis. EBioMedicine (2016) 13:339-47. doi:10.1016/j.ebiom.2016.10.024

120. Cannella D, Brenier-Pinchart M-P, Braun L, van Rooyen JM, Bougdour A, Bastien O, et al. miR-146a and miR-155 delineate a microRNA fingerprint associated with Toxoplasma persistence in the host brain. Cell Rep (2014) 6:928-37. doi:10.1016/j.celrep.2014.02.002

121. Aalaei-andabili SH, Rezaei N, Kawai T, Akira S, Kumar H, Kawai T, et al. Toll like receptor (TLR)-induced differential expression of microRNAs (miRs) and immune response against infection: a systematic review. J Infect (2013) 67:251-64. doi:10.1016/j.jinf.2013.07.016

122. Essandoh K, Li Y, Huo J, Fan G-C. miRNA-mediated macrophage polarization and its potential role in the regulation of inflammatory response. Shock (2016) 46:122-31. doi:10.1097/SHK.0000000000000604

123. Montagner S, Orlandi EM, Merante S, Monticelli S. The role of miRNAs in mast cells and other innate immune cells. Immunol Rev (2013) 253:12-24. doi:10.1111/imr.12042

124. Nahid MA, Satoh M, Chan EKL. Mechanistic role of microRNA-146a in endotoxin-induced differential cross-regulation of TLR signaling. J Immunol (2011) 186:1723-34. doi:10.4049/jimmunol.1002311

125. Quinn EM, Wang JH, O'Callaghan G, Redmond HP. MicroRNA-146a is upregulated by and negatively regulates TLR2 signaling. PLoS One (2013) 8:e62232. doi:10.1371/journal.pone.0062232

126. Siddle KJ, Tailleux L, Deschamps M, Loh Y-HE, Deluen C, Gicquel B, et al. Bacterial infection drives the expression dynamics of microRNAs and their isomiRs. PLoS Genet (2015) 11:e1005064. doi:10.1371/journal.pgen.1005064

127. Wang P, Gu Y, Zhang Q, Han Y, Hou J, Lin L, et al. Identification of resting and type I IFN-activated human NK cell miRNomes reveals microRNA-378 and microRNA-30e as negative regulators of NK cell cytotoxicity. J Immunol (2012) 189:211-21. doi:10.4049/jimmunol.1200609

128. Hou J, Wang P, Lin L, Liu X, Ma F, An H, et al. MicroRNA-146a feedback inhibits RIG-I-dependent type I IFN production in macrophages by targeting TRAF6, IRAK1, and IRAK2. J Immunol (2009) 183:2150-8. doi:10.4049/ jimmunol.0900707

129. Lai L, Song Y, Liu Y, Chen Q, Han Q, Chen W, et al. MicroRNA-92a negatively regulates toll-like receptor (TLR)-triggered inflammatory response in macrophages by targeting MKK4 kinase. J Biol Chem (2013) 288:7956-67. doi:10.1074/jbc.M112.445429

130. Wang P, Hou J, Lin L, Wang C, Liu X, Li D, et al. Inducible microRNA-155 feedback promotes type I IFN signaling in antiviral innate immunity by targeting suppressor of cytokine signaling 1. J Immunol (2010) 185:6226-33. doi:10.4049/jimmunol.1000491

131. Deng M, Hou J, Hu J, Wang S, Chen M, Chen L, et al. Hepatitis B virus mRNAs functionally sequester let-7a and enhance hepatocellular carcinoma. Cancer Lett (2016) 383:62-72. doi:10.1016/j.canlet.2016.09.028
132. Thounaojam MC, Kundu K, Kaushik DK, Swaroop S, Mahadevan A, Shankar SK, et al. MicroRNA 155 regulates Japanese encephalitis virus-induced inflammatory response by targeting Src homology 2-containing inositol phosphatase 1. J Virol (2014) 88:4798-810. doi:10.1128/JVI.02979-13

133. McCoy CE, Sheedy FJ, Qualls JE, Doyle SL, Quinn SR, Murray PJ, et al. IL-10 inhibits miR-155 induction by toll-like receptors. J Biol Chem (2010) 285:20492-8. doi:10.1074/jbc.M110.102111

134. Chen Y, Gao D-Y, Huang L. In vivo delivery of miRNAs for cancer therapy: challenges and strategies. Adv Drug Deliv Rev (2015) 81:128-41. doi:10.1016/j. addr.2014.05.009

135. Fehervari Z. MicroRNA and TH2 cells. Nat Immunol (2014) 15:832-832. doi:10.1038/ni.2975

136. Nakagawa R, Leyland R, Meyer-Hermann M, Lu D, Turner M, Arbore G, et al. MicroRNA-155 controls affinity-based selection by protecting c-MYC+ B cells from apoptosis. J Clin Invest (2015) 126:377-88. doi:10.1172/JCI82914

137. Pasqualucci L, Bhagat G, Jankovic M, Compagno M, Smith P, Muramatsu M, et al. AID is required for germinal center-derived lymphomagenesis. Nat Genet (2008) 40:108-12. doi:10.1038/ng.2007.35

138. Teng G, Hakimpour P, Landgraf P, Rice A, Tuschl T, Casellas R, et al. MicroRNA-155 is a negative regulator of activation-induced cytidine deaminase. Immunity (2008) 28:621-9. doi:10.1016/j.immuni.2008.03.015

139. Zaheen A, Martin A. Activation-induced cytidine deaminase and aberrant germinal center selection in the development of humoral autoimmunities. Am J Pathol (2011) 178:462-71. doi:10.1016/j.ajpath.2010.09.044

140. Yin Q, Wang X, McBride J, Fewell C, Flemington E. B-cell receptor activation induces BIC/miR-155 expression through a conserved AP-1 element. J Biol Chem (2008) 283:2654-62. doi:10.1074/jbc.M708218200

141. Frasca D, Diaz A, Romero M, Ferracci F, Blomberg BB. MicroRNAs miR155 and miR-16 decrease AID and E47 in B cells from elderly individuals. J Immunol (2015) 195:2134-40. doi:10.4049/jimmunol.1500520

142. KennedyRB,OvsyannikovaIG,HaralambievaIH,ObergAL,ZimmermannMT, Grill DE, et al. Immunosenescence-related transcriptomic and immunologic changes in older individuals following influenza vaccination. Front Immunol (2016) 7:450. doi:10.3389/fimmu.2016.00450

143. Cheng N-L, Chen X, Kim J, Shi AH, Nguyen C, Wersto R, et al. MicroRNA$125 \mathrm{~b}$ modulates inflammatory chemokine CCL4 expression in immune cells and its reduction causes CCL4 increase with age. Aging Cell (2015) 14:200-8. doi:10.1111/acel.12294

144. Ma L, Shen C-J, Cohen ÉA, Xiong S-D, Wang J-H. miRNA-1236 inhibits HIV-1 infection of monocytes by repressing translation of cellular factor VprBP. PLoS One (2014) 9:e99535. doi:10.1371/journal.pone.0099535

145. He J, Ji Y, Li A, Zhang Q, Song W, Li Y, et al. miR-122 directly inhibits human papillomavirus E6 gene and enhances interferon signaling through blocking suppressor of cytokine signaling 1 in SiHa cells. PLoS One (2014) 9:e108410. doi:10.1371/journal.pone.0108410

146. Lecellier C-H, Dunoyer P, Arar K, Lehmann-Che J, Eyquem S, Himber C, et al. A cellular microRNA mediates antiviral defense in human cells. Science (2005) 308:557-60. doi:10.1126/science.1108784

147. Nathans R, Chu C-Y, Serquina AK, Lu C-C, Cao H, Rana TM. Cellular microRNA and P bodies modulate host-HIV-1 interactions. Mol Cell (2009) 34:696-709. doi:10.1016/j.molcel.2009.06.003

148. Otsuka M, Jing Q, Georgel P, New L, Chen J, Mols J, et al. Hypersusceptibility to vesicular stomatitis virus infection in Dicerl-deficient mice is due to impaired miR24 and miR93 expression. Immunity (2007) 27:123-34. doi:10.1016/j.immuni.2007.05.014

149. Zheng Z, Ke X, Wang M, He S, Li Q, Zheng C, et al. Human microRNA hsa-miR-296-5p suppresses enterovirus 71 replication by targeting the viral genome. J Virol (2013) 87:5645-56. doi:10.1128/JVI.02655-12

150. LaMonte G, Philip N, Reardon J, Lacsina JR, Majoros W, Chapman L, et al. Translocation of sickle cell erythrocyte microRNAs into Plasmodium falciparum inhibits parasite translation and contributes to malaria resistance. Cell Host Microbe (2012) 12:187-99. doi:10.1016/j.chom.2012.06.007

151. Bogerd HP, Skalsky RL, Kennedy EM, Furuse Y, Whisnant AW, Flores O, et al. Replication of many human viruses is refractory to inhibition by endogenous cellular microRNAs. J Virol (2014) 88:8065-76. doi:10.1128/JVI.00985-14

152. Barnes D, Kunitomi M, Vignuzzi M, Saksela K, Andino R. Harnessing endogenous miRNAs to control virus tissue tropism as a strategy for developing attenuated virus vaccines. Cell Host Microbe (2008) 4:239-48. doi:10.1016/j. chom.2008.08.003 
153. Heiss BL, Maximova OA, Thach DC, Speicher JM, Pletnev AG. MicroRNA targeting of neurotropic flavivirus: effective control of virus escape and reversion to neurovirulent phenotype. J Virol (2012) 86:5647-59. doi:10.1128/ JVI.07125-11

154. de Candia P, Torri A, Gorletta T, Fedeli M, Bulgheroni E, Cheroni C, et al. Intracellular modulation, extracellular disposal and serum increase of miR150 mark lymphocyte activation. PLoS One (2013) 8:e75348. doi:10.1371/ journal.pone.0075348

155. Irmak MK, Erdem U, Kubar A. Antiviral activity of salivary microRNAs for ophthalmic herpes zoster. Theor Biol Med Model (2012) 9:21. doi:10.1186/ 1742-4682-9-21

156. Weber JA, Baxter DH, Zhang S, Huang DY, Huang KH, Lee MJ, et al. The microRNA spectrum in 12 body fluids. Clin Chem (2010) 56:1733-41. doi:10.1373/clinchem.2010.147405

157. Arroyo JD, Chevillet JR, Kroh EM, Ruf IK, Pritchard CC, Gibson DF, et al. Argonaute 2 complexes carry a population of circulating microRNAs independent of vesicles in human plasma. Proc Natl Acad Sci U S A (2011) 108:5003-8. doi:10.1073/pnas.1019055108

158. Vickers KC, Palmisano BT, Shoucri BM, Shamburek RD, Remaley AT. MicroRNAs are transported in plasma and delivered to recipient cells by high-density lipoproteins. Nat Cell Biol (2011) 13:423-33. doi:10.1038/ ncb2210

159. Zernecke A, Bidzhekov K, Noels H, Shagdarsuren E, Gan L, Denecke B, et al. Delivery of microRNA-126 by apoptotic bodies induces CXCL12-dependent vascular protection. Sci Signal (2009) 2:ra81. doi:10.1126/scisignal.2000610

160. Turchinovich A, Cho WC. The origin, function and diagnostic potential of extracellular microRNA in human body fluids. Front Genet (2014) 5:30. doi:10.3389/fgene.2014.00030

161. Alexander M, Hu R, Runtsch MC, Kagele DA, Mosbruger TL, Tolmachova T, et al. Exosome-delivered microRNAs modulate the inflammatory response to endotoxin. Nat Commun (2015) 6:7321. doi:10.1038/ncomms8321

162. Bell E, Taylor MA. Functional roles for exosomal microRNAs in the tumour microenvironment. Comput Struct Biotechnol J (2017) 15:8-13. doi:10.1016/j. csbj.2016.10.005

163. Lehmann SM, Krüger C, Park B, Derkow K, Rosenberger K, Baumgart J, et al. An unconventional role for miRNA: let-7 activates toll-like receptor 7 and causes neurodegeneration. Nat Neurosci (2012) 15:827-35. doi:10.1038/ nn. 3113

164. Mittelbrunn M, Gutiérrez-Vázquez C, Villarroya-Beltri C, González S, Sánchez-Cabo F, González MÁ, et al. Unidirectional transfer of microRNAloaded exosomes from $\mathrm{T}$ cells to antigen-presenting cells. Nat Commun (2011) 2:282. doi:10.1038/ncomms1285

165. Yahyaei S, Biasin M, Saulle I, Gnudi F, De Luca M, Tasca KI, et al. Identification of a specific miRNA profile in HIV-exposed seronegative individuals. J Acquir Immune Defic Syndr (2016) 73:11-9. doi:10.1097/QAI.0000000000001070

166. Ramos TL, Sánchez-Abarca LI, Muntión S, Preciado S, Puig N, López-Ruano G, et al. MSC surface markers (CD44, CD73, and CD90) can identify human MSC-derived extracellular vesicles by conventional flow cytometry. Cell Commun Signal (2016) 14:2. doi:10.1186/s12964-015-0124-8

167. Machlin ES, Sarnow P, Sagan SM. Masking the 5' terminal nucleotides of the hepatitis $\mathrm{C}$ virus genome by an unconventional microRNA-target RNA complex. Proc Natl Acad Sci U S A (2011) 108:3193-8. doi:10.1073/pnas. 1012464108

168. Sarnow P, Sagan SM. Unraveling the mysterious interactions between hepatitis C virus RNA and liver-specific microRNA-122. Annu Rev Virol (2016) 3(1):309-32. doi:10.1146/annurev-virology-110615-042409

169. O'Connor CM, Vanicek J, Murphy EA. Host microRNA regulation of human cytomegalovirus immediate early protein translation promotes viral latency. J Virol (2014) 88:5524-32. doi:10.1128/JVI.00481-14

170. Cazalla D, Yario T, Steitz JA. Down-regulation of a host microRNA by a herpesvirus saimiri noncoding RNA. Science (2010) 328:1563-6. doi:10.1126/ science. 1187197

171. Lee S, Song J, Kim S, Kim J, Hong Y, Kim Y, et al. Selective degradation of host microRNAs by an intergenic HCMV noncoding RNA accelerates virus production. Cell Host Microbe (2013) 13:678-90. doi:10.1016/j. chom.2013.05.007

172. Scheel TKH, Luna JM, Liniger M, Nishiuchi E, Rozen-Gagnon K, Shlomai A, et al. A broad RNA virus survey reveals both miRNA dependence and functional sequestration. Cell Host Microbe (2016) 19:409-23. doi:10.1016/j. chom.2016.02.007

173. Harden ME, Munger K. Perturbation of DROSHA and DICER expression by human papillomavirus 16 oncoproteins. Virology (2017) 507:192-8. doi:10.1016/j.virol.2017.04.022

174. Das K, Garnica O, Dhandayuthapani S. Modulation of host miRNAs by intracellular bacterial pathogens. Front Cell Infect Microbiol (2016) 6:79. doi:10.3389/fcimb.2016.00079

175. Sahu SK, Kumar M, Chakraborty S, Banerjee SK, Kumar R, Gupta P, et al. MicroRNA 26a (miR-26a)/KLF4 and CREB-C/EBP? regulate innate immune signaling, the polarization of macrophages and the trafficking of Mycobacterium tuberculosis to lysosomes during infection. PLoS Pathog (2017) 13:e1006410. doi:10.1371/journal.ppat.1006410

176. Bellutti F, Kauer M, Kneidinger D, Lion T, Klein R. Identification of RISCassociated adenoviral microRNAs, a subset of their direct targets, and global changes in the targetome upon lytic adenovirus 5 infection. J Virol (2015) 89:1608-27. doi:10.1128/JVI.02336-14

177. Hu M, Wang C, Li W, Lu W, Bai Z, Qin D, et al. A KSHV microRNA directly targets $\mathrm{G}$ protein-coupled receptor kinase 2 to promote the migration and invasion of endothelial cells by inducing CXCR2 and activating AKT signaling. PLoS Pathog (2015) 11:e1005171. doi:10.1371/journal.ppat.1005171

178. Kawano Y, Iwata S, Kawada J, Gotoh K, Suzuki M, Torii Y, et al. Plasma vira microRNA profiles reveal potential biomarkers for chronic active EpsteinBarr virus infection. J Infect Dis (2013) 208:771-9. doi:10.1093/infdis/jit222

179. Kim S, Lee S, Shin J, Kim Y, Evnouchidou I, Kim D, et al. Human cytomegalovirus microRNA miR-US4-1 inhibits CD8+ $\mathrm{T}$ cell responses by targeting the aminopeptidase ERAP1. Nat Immunol (2011) 12:984-91. doi:10.1038/ni.2097

180. Liu Y, Sun J, Zhang H, Wang M, Gao GF, Li X. Ebola virus encodes a miR155 analog to regulate importin- $\alpha 5$ expression. Cell Mol Life Sci (2016) 73:3733-44. doi:10.1007/s00018-016-2215-0

181. Sampey GC, Saifuddin M, Schwab A, Barclay R, Punya S, Chung M-C, et al. Exosomes from HIV-1-infected cells stimulate production of proinflammatory cytokines through trans-activating response (TAR) RNA. J Biol Chem (2016) 291:1251-66. doi:10.1074/jbc.M115.662171

182. Tuddenham L, Jung JS, Chane-Woon-Ming B, Dölken L, Pfeffer S. Small RNA deep sequencing identifies microRNAs and other small noncoding RNAs from human herpesvirus 6B. J Virol (2012) 86:1638-49. doi:10.1128/ JVI.05911-11

183. Umbach JL, Kramer MF, Jurak I, Karnowski HW, Coen DM, Cullen BR. MicroRNAs expressed by herpes simplex virus 1 during latent infection regulate viral mRNAs. Nature (2008) 454:780-3. doi:10.1038/ nature 07103

184. Liu X, Happel C, Ziegelbauer JM. Kaposi's sarcoma-associated herpesvirus microRNAs target GADD45B To protect infected cells from cell cycle arrest and apoptosis. J Virol (2017) 91:e02045-16. doi:10.1128/JVI.02045-16

185. Skalsky RL, Samols MA, Plaisance KB, Boss IW, Riva A, Lopez MC, et al. Kaposi's sarcoma-associated herpesvirus encodes an ortholog of miR-155. J Virol (2007) 81:12836-45. doi:10.1128/JVI.01804-07

186. Devhare PB, Sasaki R, Shrivastava S, Di Bisceglie AM, Ray R, Ray RB. Exosome-mediated intercellular communication between hepatitis C virus-infected hepatocytes and hepatic stellate cells. J Virol (2017) 91:e22252216. doi:10.1128/JVI.02225-16

187. Gallo A, Vella S, Miele M, Timoneri F, Di Bella M, Bosi S, et al. Global profiling of viral and cellular non-coding RNAs in Epstein-Barr virus-induced lymphoblastoid cell lines and released exosome cargos. Cancer Lett (2017) 388:334-43. doi:10.1016/j.canlet.2016.12.003

188. Kalamvoki M, Du T, Roizman B. Cells infected with herpes simplex virus 1 export to uninfected cells exosomes containing STING, viral mRNAs, and microRNAs. Proc Natl Acad Sci U S A (2014) 111:E4991-6. doi:10.1073/ pnas.1419338111

189. Kouwaki T, Okamoto M, Tsukamoto H, Fukushima Y, Oshiumi H. Extracellular vesicles deliver host and virus RNA and regulate innate immune response. Int J Mol Sci (2017) 18:666. doi:10.3390/ijms18030666

190. Mohammad AA, Costa H, Landázuri N, Lui WO, Hultenby K, Rahbar A, et al. Human cytomegalovirus microRNAs are carried by virions and dense bodies and are delivered to target cells. J Gen Virol (2017) 98:1058-72. doi:10.1099/jgv.0.000736 
191. Furuse Y, Finethy R, Saka HA, Xet-Mull AM, Sisk DM, Smith KLJ, et al. Search for microRNAs expressed by intracellular bacterial pathogens in infected mammalian cells. PLoS One (2014) 9:e106434. doi:10.1371/journal. pone. 0106434

192. Wang X, Gu H, Qin D, Yang L, Huang W, Essandoh K, et al. Exosomal miR-223 contributes to mesenchymal stem cell-elicited cardioprotection in polymicrobial sepsis. Sci Rep (2015) 5:13721. doi:10.1038/srep13721

193. Zhang T, Yu J, Zhang Y, Li L, Chen Y, Li D, et al. Salmonella enterica serovar enteritidis modulates intestinal epithelial miR-128 levels to decrease macrophage recruitment via macrophage colony-stimulating factor. J Infect Dis (2014) 209:2000-11. doi:10.1093/infdis/jiu006

194. van der Ree MH, van der Meer AJ, de Bruijne J, Maan R, van Vliet A, Welzel TM, et al. Long-term safety and efficacy of microRNA-targeted therapy in chronic hepatitis C patients. Antiviral Res (2014) 111:53-9. doi:10.1016/j.antiviral.2014.08.015

195. van der Ree MH, de Vree JM, Stelma F, Willemse S, van der Valk M, Rietdijk S, et al. Safety, tolerability, and antiviral effect of RG-101 in patients with chronic hepatitis C: a phase $1 \mathrm{~B}$, double-blind, randomised controlled trial. Lancet (2017) 389(10070):709-17. doi:10.1016/S0140-6736(16)31715-9

196. Stelma F, van der Ree MH, Sinnige MJ, Brown A, Swadling L, de Vree JML, et al. Immune phenotype and function of natural killer and T cells in chronic hepatitis C patients who received a single dose of anti-microRNA-122, RG-101. Hepatology (2017) 66(1):57-68. doi:10.1002/hep.29148

197. Beg MS, Brenner AJ, Sachdev J, Borad M, Kang Y-K, Stoudemire J, et al. Phase I study of MRX34, a liposomal miR-34a mimic, administered twice weekly in patients with advanced solid tumors. Invest New Drugs (2017) 35:180-8. doi:10.1007/s10637-016-0407-y

198. Reid G, Pel ME, Kirschner MB, Cheng YY, Mugridge N, Weiss J, et al. Restoring expression of miR-16: a novel approach to therapy for malignant pleural mesothelioma. Ann Oncol (2013) 24:3128-35. doi:10.1093/annonc/ mdt412

199. Boon RA, Vickers KC. Intercellular transport of microRNAs. Arterioscler Thromb Vasc Biol (2013) 33:186-92. doi:10.1161/ATVBAHA.112.300139

200. Zhang X, Guo J, Fan S, Li Y, Wei L, Yang X, et al. Screening and identification of six serum microRNAs as novel potential combination biomarkers for pulmonary tuberculosis diagnosis. PLoS One (2013) 8:e81076. doi:10.1371/ journal.pone.0081076

201. Cui L, Qi Y, Li H, Ge Y, Zhao K, Qi X, et al. Serum microRNA expression profile distinguishes enterovirus 71 and coxsackievirus 16 infections in patients with hand-foot-and-mouth disease. PLoS One (2011) 6:e27071. doi:10.1371/ journal.pone.0027071

202. El-Diwany R, Wasilewski LN, Witwer KW, Bailey JR, Page K, Ray SC, et al. Acute hepatitis $\mathrm{C}$ virus infection induces consistent changes in circulating microRNAs that are associated with nonlytic hepatocyte release. JVirol (2015) 89:9454-64. doi:10.1128/JVI.00955-15

203. Jin B-X, Zhang Y-H, Jin W-J, Sun X-Y, Qiao G-F, Wei Y-Y, et al. MicroRNA panels as disease biomarkers distinguishing hepatitis B virus infection caused hepatitis and liver cirrhosis. Sci Rep (2015) 5:15026. doi:10.1038/srep15026
204. Yen Y-H, Huang C-M, Wei K-L, Wang J-H, Lu S-N, Lee C-M, et al. MicroRNA-122 as a predictor of HBsAg seroclearance in hepatitis B and C dual infected patients treated with interferon and ribavirin. Sci Rep (2016) 6:33816. doi:10.1038/srep33816

205. Waidmann O, Bihrer V, Kronenberger B, Zeuzem S, Piiper A, Forestier N. Pretreatment serum microRNA-122 is not predictive for treatment response in chronic hepatitis C virus infection. Dig Liver Dis (2012) 44:438-41. doi:10.1016/j.dld.2011.11.011

206. Perez JT, Pham AM, Lorini MH, Chua MA, Steel J, tenOever BR. MicroRNAmediated species-specific attenuation of influenza A virus. Nat Biotechnol (2009) 27:572-6. doi:10.1038/nbt.1542

207. Brostoff T, Pesavento PA, Barker CM, Kenney JL, Dietrich EA, Duggal NK, et al. MicroRNA reduction of neuronal West Nile virus replication attenuates and affords a protective immune response in mice. Vaccine (2016) 34:5366-75. doi:10.1016/j.vaccine.2016.08.063

208. Heiss BL, Maximova OA, Pletnev AG. Insertion of microRNA targets into the flavivirus genome alters its highly neurovirulent phenotype. J Virol (2011) 85:1464-72. doi:10.1128/JVI.02091-10

209. Shen X, Sun W, Shi Y, Xing Z, Su X. Altered viral replication and cell responses by inserting microRNA recognition element into $\mathrm{PB} 1$ in pandemic influenza A virus (H1N1) 2009. Mediators Inflamm (2015) 2015:976575. doi:10.1155/2015/976575

210. Tan M, Sun W, Feng C, Xia D, Shen X, Ding Y, et al. The microRNA-let-7bmediated attenuated strain of influenza A (H1N1) virus in a mouse model. J Infect Dev Ctries (2016) 10:973-81. doi:10.3855/jidc.6861

211. Tsetsarkin KA, Liu G, Volkova E, Pletnev AG. Synergistic internal ribosome entry site/microRNA-based approach for flavivirus attenuation and live vaccine development. MBio (2017) 8:e2326-2316. doi:10.1128/mBio. 02326-16

212. Wheatley AK, Kramski M, Alexander MR, Toe JG, Center RJ, Purcell DFJ. Co-expression of miRNA targeting the expression of PERK, but not PKR, enhances cellular immunity from an HIV-1 Env DNA vaccine. PLoS One (2011) 6:e18225. doi:10.1371/journal.pone.0018225

213. NIH Office of Strategic Coordination - The Common Fund. Extracellular RNA Communication NIH Common Fund. (2017). Available from: https:// commonfund.nih.gov/Exrna/index

Conflict of Interest Statement: The authors declare that the research was conducted in the absence of any commercial or financial relationships that could be construed as a potential conflict of interest.

Copyright (c) 2017 Drury, O'Connor and Pollard. This is an open-access article distributed under the terms of the Creative Commons Attribution License (CC BY). The use, distribution or reproduction in other forums is permitted, provided the original author(s) or licensor are credited and that the original publication in this journal is cited, in accordance with accepted academic practice. No use, distribution or reproduction is permitted which does not comply with these terms. 